\title{
Heterogeneous Firm-Level Responses to Trade Liberalization: A Test Using Stock Price Reactions*
}

\author{
Holger Breinlich ${ }^{\dagger}$
}

March 2014

\begin{abstract}
This paper presents novel empirical evidence on key predictions of heterogeneous firm models by examining stock market reactions to the Canada-United States Free Trade Agreement of 1989 (CUSFTA). I derive testable predictions for a class of models based on Melitz (2003). Using the uncertainty surrounding CUSFTA's ratification, I show that the pattern of abnormal returns of Canadian manufacturing firms was strongly consistent with predictions related to export (U.S.) tariff reductions, but less so with predictions related to import (Canadian) tariff reductions. Lower Canadian tariffs did have an effect through the implied reduction in intermediate input tariffs, however.
\end{abstract}

KEY WORDS: Heterogeneous Firm Models, Stock Market Event Studies, Canada-U.S. Free Trade Agreement

JEL CLASSIFICATION: F12, F14, G14

\section{Introduction}

The last decade has seen a revolution in the theoretical analysis of trade liberalization episodes. Since the seminal contribution by Melitz (2003), models with heterogeneous firms have all but replaced traditional modeling approaches with homogeneous firms. The key innovation of Melitz and subsequent extensions was to show how trade liberalization leads to aggregate productivity gains through intra-industry reallocation. The mechanism underlying this reallocation is the differential impact of trade liberalization on exporting and non-exporting firms. While exporters benefit from increased access to foreign markets, non-exporters suffer lower profits due to increased product and factor market competition. Together with the assumption that exporters are more productive than non-exporters, the ensuing reallocation of market shares towards exporting firms raises aggregate productivity.

${ }^{*}$ I am grateful to Ariel Burstein, three anonymous referees, Alejandro Cuñat, Dave Donaldson, Samuel Kortum, Ralph Ossa and seminar participants at the London School of Economics, EIIT 2009, VfSP 2010, GIST 2011 and the Universities of Nottingham, Mannheim, Rotterdam, Copenhagen, Oxford, Chicago, Essex, Munich and Sussex for helpful comments and suggestions. All remaining errors are mine.

${ }^{\dagger}$ University of Essex, CEP and CEPR. Address: Wivenhoe Park, Colchester CO4 3SQ, United Kingdom. Tel.: +44 1206 872768. Fax: +44 1206 872724. Email: hbrein@essex.ac.uk. 
Many of the assumptions and predictions of heterogeneous firm models are consistent with evidence from a large empirical literature which has emerged over the years. The strongest evidence is available for the productivity advantage of exporters, and for the self-selection of more productive firms into export markets (e.g., Bernard et al. (2007)). ${ }^{1}$ Tybout (2001) summarizes several papers which show that trade liberalization episodes were accompanied by market share reallocations. A smaller literature also provides more direct evidence on the impact of lower trade costs on the reallocation of market shares between exporters and non-exporters (e.g., Trefler (2004), Bernard, Jensen and Schott (2006)). ${ }^{2}$

A common feature of all empirical studies to date is their ex-post character. That is, they track the firm- or sector-level variables of interest for a number of years and try to isolate the impact of trade policy changes from a large number of confounding factors. Depending on the specific setting of the liberalization episode, this can pose considerable econometric challenges (see, for example, Tybout, 2001).

In this paper, I take a different approach to providing evidence for the differential impact of trade liberalization across firms. I do so by using stock market reactions surrounding the implementation process of the Canada-United States Free Trade Agreement of 1989 (henceforth, CUSFTA). Under the assumption that unanticipated changes in the likelihood of CUSFTA's implementation are sufficiently rapidly reflected in stock prices, price reactions contain information about changes in future profits and can be used to test heterogeneous firm models.

The key advantage of such an event study approach over traditional ex-post evaluations is that the number of confounding factors is much more limited. Only factors about which expectations change during my one- to two-day event windows will have the potential to contaminate the estimates. Secondly, from a conceptual point of view, event studies present an interesting alternative to ex-post tests of heterogenous firm models. These models essentially make predictions about changes in future per-period profits brought about by trade liberalizations. To the extent that expectations about these changes will be reflected in stock prices, analyzing price reactions will be conceptually closer to the models' theoretical predictions than looking at realized firm-level variables ex-post. ${ }^{3}$

CUSFTA is particularly well suited for providing evidence on heterogeneous firm models in general, and for event study evidence, in particular. First, CUSFTA was a clearly defined policy experiment in the sense that it was neither introduced in response to a macroeconomic shock nor part of a larger package of reforms (Trefler, 2004). Second, the main instrument of liberalization - tariff cuts - is easily quantifiable and has a direct theoretical counterpart in heterogeous firm

\footnotetext{
${ }^{1} \mathrm{~A}$ few studies have also found productivity gains from exporting (e.g., De Loecker, 2007), or have noted that exporting and productivity-increasing investments are complementary activities (e.g., Bustos, 2011). But even in this literature, the consensus is that new and existing exporters are more productive to begin with than firms which remain non-exporters.

${ }^{2}$ See Burstein and Cravino (2014) and Breinlich and Cuñat (2013) for the predictions of trade models with heterogeneous firms with respect to measured productivity, i.e., productivity as measured in the data used by the empirical studies cited above.

${ }^{3}$ Looking at stock price reactions also brings additional challenges as compared to traditional ex-post approaches. By construction, my sample consists of publicly traded firms which are relatively large. The accounting data available for these firm is also incomplete as far as export status is concerned. A final concern is that stock market event studies present a joint test of both the theory in question and the efficient markets hypothesis (e.g., Campbell et al., 1997). Below, I present detailed arguments as to why none of these issues is likely to affect my results qualitatively, although they might make a quantitative interpretation more challenging.
} 
models. In addition, CUSFTA was a reciprocal agreement and is as such suitable for analyzing the differential impact of domestic and foreign tariffs. This distinction is a key element of many of the more recent heterogeneous firm models such as Melitz and Ottaviano (2008) or Chaney (2008). Third, as I will discuss in more detail below, the cross-sectoral variation in tariff cuts was both substantial and largely exogenous, allowing for the implementation of a difference-indifferences estimation strategy within my event study framework. Finally, and more specifically relevant for an event study, CUSFTA was the main election issue in the Canadian federal election of November 1988. Both the election itself as well as a number of events in its run-up provide unanticipated changes in the likelihood of CUSFTA's implementation which is essential for the successful implementation of an event study.

My analysis proceeds in two steps. I first show how stock price reactions can be used to test heterogeneous firm models, and use a simple model of this class based on Chaney (2008) to derive testable predictions for the remaining sections. I then proceed to a test of these predictions, using unanticipated changes in the likelihood of CUSFTA's implementation to analyze withinsector differences in abnormal stock market returns. In practice, my estimation strategy will compare the stock returns of firms which vary along a number of characteristics. I use firm size (as measured by sales) in most specifications but also look at employment, productivity and export status. In addition to improving data availability, such a broad-based approach has several advantages. First, heterogeneous firm models make predictions about stock market reactions of small vs large and less vs more productive firms, in addition to reactions of new and existing exporters vs non-exporting firms. As I explain below, using sales (or employment or productivity) in addition to export status also helps addressing the difficulty of identifying new exporters in the data and provides more direct evidence for the intra-industry reallocation predicted by models in the tradition of Melitz (2003).

My findings are broadly supportive of the predictions of heterogeneous firm models. The election victory of the ruling Progressive Conservatives (a strong supporter of CUSFTA) led to significant stock market gains of large relative to small firms (and of more productive relative to less productive, and exporting relative to non-exporting firms). In contrast, opinion polls in the run-up to the election showing a substantial lead for the oppositional Liberal Party (who were opposed to CUSFTA) resulted in the opposite stock market return differences.

In order to address the possibility that a Conservative election victory may have affected different types of firms differently through channels other than CUSFTA, I compare betweenfirm return differences across industries with different extents of tariff cuts. Consistent with theoretical predictions, I find that the relative gains and losses of larger (and more productive and exporting) firms were indeed significantly higher in sectors with larger U.S. tariff cuts. These results are robust to including a number of control variables such as changes in intermediate input tariffs and firms' multinational status.

As a further check on my results, I also examine stock market reactions to two earlier events which were directly related to CUSFTA but not the election itself: the reaching of an agreement on CUSFTA after difficult negotiations between the U.S. and Canada in October 1987; and the refusal of the Canadian Senate to ratify the agreement in July 1988. I again find that stock prices of larger firms increased relative to those of smaller firms in reaction to the first event, 
and decreased in response to the second event. As before, reactions were stronger in sectors with higher future U.S. tariff cuts. Finally, I also perform placebo checks by looking at stock market reactions on dates on which no new information about CUSFTA was revealed. Consistent with theoretical predictions, I do not find significant effects in these additional regressions.

My results are less conclusive with respect to the effects of reductions in Canadian import tariffs. Most results suggests that larger Canadian firms also gained relative to smaller firms in response to such tariff cuts. However, the corresponding coefficient estimates are generally small and have the wrong sign for some specifications and events. Interestingly, as I discuss below, these weaker results correspond to less clear-cut theoretical predictions of heterogeneous firm models with respect to import tariff liberalization (as opposed to export tariff reductions), in the sense that the predictions of existing models seem to partially depend on specific modeling assumptions such as demand and cost structures. Some of my results suggest, however, that Canadian tariff cuts did matter for differential profit responses through other channels, in particular through reductions in the intermediate input tariffs industries face.

While my main results are all of a qualitative nature, I also try to provide a sense of the quantitative importance and plausibility of the estimated return differences. To this end, I calculate the CUSFTA-induced change in the expected future profits of active firms implied by my estimates. Based on assumptions about the change in the likelihood of CUSFTA's implementation brought about by the Conservative election victory, I estimate that CUSFTA increased the within-industry difference in per-period profits of smaller and larger firms by around $6 \%-7 \%$ in the most plausible scenarios, and up to $14 \%$ under more extreme assumptions.

While stock market event studies are frequently employed in the corporate finance literature, they have rarely been used to test theories of international trade. Exceptions include Grossman and Levinsohn (1989), who use stock market returns to provide evidence in favor of the specific-factors model of trade, and a small number of papers which analyze stock market reactions to trade policy announcements concerning specific industries, such as the imposition of antidumping duties (e.g., Hartigan et al., 1986 and 1989; Hughes et al., 1997; Bloningen et al., 2004). ${ }^{4}$ To the best of my knowledge, the present paper is the first to analyze stock market reactions to a broad-based trade liberalization episode and link the results to recent theories of international trade. While my focus is on testing models of heterogeneous firms in the tradition of Melitz (2003), some of my robustness checks also provide complementary evidence to existing results from ex-post approaches for the effect of reductions in intermediate input tariffs and the differential impact of trade liberalization on multinational and domestic firms (see Bloningen (2005); Amiti and Konings (2007); Topalova and Khandelwal (2011); Halpern et al. (2011)). The use of cross-sectional variation in tariff cuts to implement a difference-in-differences approach within the event study framework is also novel and substantially increases the potential for convincing econometric identification. Finally, the present paper seems to be the first to attempt a quantification of the differential impact of trade liberalizations on the profits of firms within an industry, which is the driving force behind subsequent market share reallocations.

\footnotetext{
${ }^{4}$ There are also a few studies which look at stock market movements during the Canadian election campaign from 1988 in different contexts. Together with the press coverage of the campaign and a number of political science studies, these inform my choice of events and are cited in more detail in Section 3 below.
} 
The rest of this paper is structured as follows. Section 2 discusses how stock price reactions can be used to test heterogeneous firm models, and uses a simple model of this class to derive testable predictions for the remaining sections. Section 3 describes CUSFTA and the specific events I study in more detail. Section 4 discusses the event study methodology and describes the data sources used. Section 5 presents the empirical results and Section 6 concludes.

\section{Theoretical Predictions}

In this section, I first explain the link between stock market prices and firm profits. I then discuss the predictions of heterogeneous firm models with respect to tariff-cut-induced profit changes. In Section 2.2, I use a heterogeneous firm model based on Chaney (2008) which is simple enough to demonstrate the mechanisms at work, yet sufficiently flexible to accomodate asymmetric countries and tariff barriers, two key features of CUSFTA. Section 2.3 discusses to what extent these insights carry over to more general settings. The online appendix to this paper provides analytical results for two popular extensions of Melitz (2003), the original Chaney (2008) model and the model by Melitz and Ottaviano (2008). ${ }^{5}$

\subsection{Linking Stock Prices to Expected Profits}

The standard approach to linking stock prices and expected profits is the dividend discount model (see Brealey and Myers, 2000). The dividend discount model states that the price of firm $i^{\prime}$ s shares at time $t$ equals the net present value of its future stream of dividends per share:

$$
p_{i t}=\sum_{s=1}^{\infty} \frac{E\left(D I V_{i} \mid I_{t}\right)}{\left(1+e_{i}\right)^{s}}=\frac{E\left(D I V_{i} \mid I_{t}\right)}{e_{i}}
$$

where $E\left(D I V_{i} \mid I_{t}\right)$ is the expected value of future per-period dividends per share of firm $i$, given information available on date $t\left(I_{t}\right)$, and $e_{i}$ is the expected return on securities in the same risk class as firm $i$. Assuming that firms disburse all profits as dividends, or that profits are reinvested at an internal rate of return equal to $e_{i}$, share prices are simply the net present value of expected future profits per share: ${ }^{6}$

$$
p_{i t}=\sum_{s=1}^{\infty} \frac{E\left(\pi_{i} \mid I_{t}\right)}{\left(1+e_{i}\right)^{s}}=\frac{E\left(\pi_{i} \mid I_{t}\right)}{e_{i}}
$$

Now consider the stock price reactions of any two firms $i$ and $i^{\prime}$ to an event which changes expectations about future profits of these firms. Denoting the event-induced stock market returns by $r_{E_{i}}$ and $r_{E_{i^{\prime}}}$, the return difference between firms $i$ and $i^{\prime}$ is given by:

$$
r_{E, i}-r_{E, i^{\prime}}=\frac{E\left(\pi_{i} \mid I_{t+\varepsilon}\right)}{E\left(\pi_{i} \mid I_{t}\right)}-\frac{E\left(\pi_{i^{\prime}} \mid I_{t+\varepsilon}\right)}{E\left(\pi_{i^{\prime}} \mid I_{t}\right)}
$$

where $I_{t+\varepsilon}$ is the new information set. What matters for the difference in event-induced stock market returns is thus the change in expected future profits of firm $i$ relative to firm $i^{\prime}$ upon

\footnotetext{
${ }^{5}$ The online appendix is available at http://privatewww.essex.ac.uk/ hbrein/.

${ }^{6}$ It is straightforward to allow for growth in expected profits and dividends, or for positive net present value projects (see Brealey and Myers, 2000). Note that $e_{i}$ also controls for differences in survival probabilities across firms, so that the summation is always from $s=1$ to infinity.
} 
the arrival of new information (regarding the likelihood of CUSFTA's implementation in the present case). ${ }^{7}$ Since models of heterogeneous firms make predictions about these profit changes, and how they vary across firms with different sizes, productivity levels, or export status, stock market returns in response to unanticipated events can be used to implement empirical tests of this class of models.

Note that for testing the qualitative predictions of heterogeneous firm models, the assumptions underlying my derivations can be substantially relaxed. For example, one could allow for more complex connections between dividends and profits, as long as the positive correlation between changes in both variables is preserved. Likewise, it is not required that stock prices fully and immediately reflect all relevant information. All that is needed is that new information about the likelihood of CUSFTA's implementation is priced in to a statistically detectable extent within a period of one or two days (the standard length of my event windows). Given the importance of CUSFTA in the Canadian election campaign of 1988 and for the Canadian economy more generally, it seems reasonable that at least some market participants reacted quickly to the Conservatives' election victory and were able to judge CUSFTA's impact on firm profits, at least in terms of the direction of the change if not its exact magnitude. Note, in particular, that the extent of tariff cuts across sectors had been publicly known even before the successful conclusion of negotiations in October 1987 (see Section 3 for details).

\subsection{Firm-Level Profits and Trade Liberalization}

I now turn to a formal discussion of how firm profits change after trade liberalization in a version of the model by Chaney (2008). Consider a setting with $N$ potentially asymmetric countries. A representative consumer in each country derives utility from the consumption of goods from $S+1$ sectors. The first $S$ sectors each produce a continuum of differentiated goods $\left(Q_{s n}\right)$ and the remaining sector provides a single homogenous good $\left(A_{n}\right)$ :

$$
U_{n}=\sum_{s=1}^{S} \mu_{n s} \ln Q_{n s}+A_{n}, \quad Q_{n s}=\left[\int_{\phi \in \Phi_{s n}} q_{n s}(\phi)^{\frac{\sigma_{s}-1}{\sigma_{s}}} d \phi\right]^{\frac{\sigma_{s}}{\sigma_{s}-1}}
$$

where $\Phi_{s n}$ presents the set of available varieties of $\operatorname{good} Q_{n s}$, and $\sigma_{s}>1$ is the elasticity of substitution between any two varieties in sector $s$. Associated with $Q_{n s}$ is a price index $P_{n s}^{1-\sigma_{s}}=\left[\int_{\phi \in \Phi_{n s}} p_{n s}(\phi)^{1-\sigma_{s}} d \phi\right]$, where $p_{n s}(\phi)$ is the price of variety $\phi$ in sector $s$, country $n$. Good $A$ is freely traded and I choose its price as the numéraire. With this setup, demand for individual varieties is $q_{n s}(\phi)=p_{n s}(\phi)^{-\sigma_{s}} P_{n s}^{\sigma_{s}-1} \mu_{n s}$.

I choose parameter values such that all countries produce positive amounts of the numéraire. Labor is mobile between sectors but immobile across countries. The numéraire sector operates under perfect competition and with a linear production function. As usual, profit maximization implies that wages in country $n$ are equal to labor productivity $\left(\theta_{A_{n}}\right), w_{n}=\theta_{A_{n}}$.

\footnotetext{
${ }^{7}$ Note that I assume that discount rates $\left(e_{i}\right)$ stay constant in the derivation of (2). As an approximation, (2) also holds if the $e_{i}$ change by the same factor for both firms. Likewise, in the empirical analysis I will require that discount rates are either constant or that their changes are uncorrelated with the firm characteristic (sales, export status etc.) along which I compare firms' stock return reactions to CUSFTA-related events. I discuss issues related to discount rates in more detail in my robustness checks in Section 5.2. There, I also provide evidence that changes in discount rates in response to my events are unlikely to substantially bias my results.
} 
The differentiated goods are produced using labor as the only factor of production. Firms vary in productivity levels, $\phi$, and have unit labor requirements of $l(\phi)=q / \phi$. In order to ship goods from country $i$ to country $j$, firms in sector $s$ also have to pay an (ad-valorem) tariff of $t_{i j}^{s}$. In accordance with my empirical analysis, I focus on tariffs here and abstract from additional trade costs. However, in the online appendix I show that all of the following results go through when I use standard iceberg-type trade costs. Finally, a firm in country $i$ selling goods to country $j$ in sector $s$ has to pay a fixed cost of $f_{i j}^{s}$ in terms of the numéraire. Thus, firm profits from selling to market $j$ are $\pi_{i j}^{s}(q, \phi)=\left(1-t_{i j}^{s}\right) p_{i j}^{s} q-\frac{w_{i}}{\phi} q-f_{i j}^{s}$.

Each firm in the differentiated goods sectors is a monopolist for the variety it produces and sets market-specific prices at $p_{i j}=\frac{\sigma}{\sigma-1} \frac{w_{i}}{\phi\left(1-t_{i j}\right)}$. There are a large number $\left(M_{n s}\right)$ of potential entrants in each country and sector which have to decide in which of the $N$ countries to sell. Productivity levels $\phi$ are known to firms before entry. In equilibrium, only firms which can earn non-negative profits in a given market will serve that market, leading to market-specific productivity cutoffs, $\phi_{i j, s}^{*}$. Finally, I assume that firm productivity $\phi$ in country $n$, sector $s$, is Pareto distributed with density $v_{n s}(\phi)=a_{s}\left(k_{n s}\right)^{a_{s}} \phi^{-\left(a_{s}+1\right)}$, where $k_{n s}>0, a_{s}>\sigma_{s}-1$ and $\phi \geq k_{n s}$. For notational ease, I focus on a single sector and drop the subscript $s$ from now on.

Under the above assumptions I obtain a solution for the entry cutoffs $\phi_{i j}^{*}$ in each sector as:

$$
\phi_{i j}^{*}=A \times\left(w_{i}\left(1-t_{i j}\right)^{-\frac{\sigma}{\sigma-1}}\left(f_{i j}\right)^{\frac{1}{\sigma-1}} \mu_{j}^{-\frac{1}{a}}\right) \times\left(\sum_{n}\left(1-t_{n j}\right)^{\frac{\sigma a-(\sigma-1)}{\sigma-1}}\left(w_{n}\right)^{-a} M_{n} k_{n}^{a} f_{n j}^{\frac{\sigma-a-1}{\sigma-1}}\right)^{1 / a}
$$

where $A$ collects constant terms. If a firm is active in market $j$, its profits there can be expressed as a function of the relevant entry cutoff. Total profits of a firm with productivity $\phi$ are:

$$
\pi_{i}(\phi)=\sum_{n} \pi_{i n}(\phi)=\phi^{\sigma-1} \sum_{n} \max \left(\left[\left(\phi_{i n}^{*}\right)^{1-\sigma}-\phi^{1-\sigma}\right] f_{i n}, 0\right)
$$

I look at the impact of tariff reductions between Canada $(i)$ and the United States $(j)$ on Canadian firms' profits. I do so separately for Canadian and U.S. tariffs, in analogy to the empirical analysis below which tries to disentangle the effect of reductions in each of these two tariffs. In the model, tariff cuts correspond to a lowering of $t_{i j}$ (U.S. import tariff) and $t_{j i}$ (Canadian import tariff). Because of quasi-linear preferences and the assumption of a fixed number of incumbents, third market profits of Canadian firms will not be affected by changes in U.S. or Canadian import tariffs (see expression (4)). Thus, it is sufficient to analyze changes in domestic profits $\left(\pi_{i i}\right)$ and in profits from exports to the U.S. $\left(\pi_{i j}\right){ }^{8}$

I first look at the effect of lower U.S. tariffs. For firms which export both before and after liberalization, I have:

$$
\frac{\Delta \pi_{X}\left(\phi, t_{i j}, t_{i j}^{\prime}\right)}{\pi_{X}(\phi)}=\frac{\phi^{\sigma-1} f_{i j}\left(\phi_{i j}^{*^{\prime} 1-\sigma}-\phi_{i j}^{* 1-\sigma}\right)}{\pi_{X}(\phi)}>0
$$

\footnotetext{
${ }^{8}$ In the following, I assume parameter values such that $\gamma_{i n}^{*}>\gamma_{i i}^{*}$ for all $n$. Thus, all active firms serve the domestic market but only the more productive firms export (which is the empirically relevant case).
} 
where $t_{i j}$ denotes the initial tariff and $t_{i j}^{\prime}$ the new (lower) tariff. The relative profit change for existing exporters is positive because from (4), the domestic cutoff is not affected and the U.S. export cutoff falls, $\phi_{i j}^{*^{\prime}}<\phi_{i j}^{*}$. For firms which export neither before nor after the tariff reduction, U.S. profits $\left(\pi_{i j}\right)$ are zero and the percentage change in profits after a lowering of U.S. tariffs is also zero because the domestic cutoff is not affected:

$$
\frac{\Delta \pi_{D O M}\left(\phi, t_{i j}, t_{i j}^{\prime}\right)}{\pi_{D O M}(\phi)}=\frac{\phi^{\sigma-1} f_{i i}\left(\phi_{i i}^{*^{\prime} 1-\sigma}-\phi_{i i}^{* 1-\sigma}\right)}{\pi_{D O M}(\phi)}=0
$$

Finally, for firms which start exporting only after U.S. tariffs have been reduced, we have:

$$
\frac{\Delta \pi_{S}\left(\phi, t_{i j}, t_{i j}^{\prime}\right)}{\pi_{S}(\phi)}=\frac{\left(\phi_{i j}^{*^{\prime}}\right)^{1-\sigma} \phi^{\sigma-1} f_{i j}-f_{i j}}{\pi_{S}(\phi)}>0
$$

Thus, existing and new exporters observe stronger relative profit increases than purely domestic firms. From (2), we should thus observe a positive difference in stock market returns between new and existing exporters and non-exporters upon the arrival of new information making an implementation of CUSFTA more likely. ${ }^{9}$

Next, consider a reduction in Canadian tariffs from $t_{j i}$ to $t_{j i}^{\prime}$. From (4), the export cutoff $\phi_{i j}^{*}$ will not be affected whereas the domestic entry cutoff $\phi_{i i}^{*}$ will rise $\left(\phi_{i i}^{*^{\prime}}>\phi_{i i}^{*}\right)$. Thus, only domestic profits will be affected. The implied change in total profits of exporting firms will be:

$$
\frac{\Delta \pi_{X}\left(\phi, t_{j i}, t_{j i}^{\prime}\right)}{\pi_{X}(\phi)}=\frac{\phi^{\sigma-1} f_{i i}\left(\phi_{i i}^{*^{\prime} 1-\sigma}-\phi_{i i}^{* 1-\sigma}\right)}{\pi_{X}(\phi)}<0
$$

For non-exporters which continue to serve the Canadian market we have:

$$
\frac{\Delta \pi_{D O M}\left(\phi, t_{j i}, t_{j i}^{\prime}\right)}{\pi_{D O M}(\phi)}=\frac{\phi^{\sigma-1} f_{i i}\left(\phi_{i i}^{*^{\prime} 1-\sigma}-\phi_{i i}^{* 1-\sigma}\right)}{\pi_{D O M}(\phi)}<\frac{\Delta \pi_{X}\left(\phi, \tau_{j i}, \tau_{j i}^{\prime}\right)}{\pi_{X}(\phi)}
$$

So both exporters and non-exporters lose but losses in percentage terms are more severe for non-exporters. Intuitively, the part of exporters' total profit derived from the U.S. market is not affected by Canadian tariff cuts, so that the relative decline in total profits is smaller. Secondly, exporters are more productive and spread the market-specific fixed costs over a larger amount of sales. The percentage decline in domestic profits alone will thus also be smaller.

Finally, the least productive Canadian firms will exit the domestic market:

$$
\frac{\Delta \pi_{E X I T}\left(\phi, t_{j i}, t_{j i}^{\prime}\right)}{\pi_{E X I T}(\phi)}=\frac{0-\left(\phi_{i i}^{* 1-\sigma} \phi^{\sigma-1} f_{i i}-f_{i i}\right)}{\pi_{E X I T}(\phi)}=-1<\frac{\Delta \pi_{D O M}\left(\phi, t_{j i}, t_{j i}^{\prime}\right)}{\pi_{D O M}(\phi)}
$$

Thus, Canadian tariff reductions will reduce profits of all Canadian firms but exporters will be

\footnotetext{
${ }^{9}$ Note that it is not possible to unambiguously rank the relative profit changes of existing exporters and new exporters. While the most productive new exporter will have a higher percentage profit change than all existing exporters, the least productive new entrant will have a relative change lower than that of all firms already exporting. In contrast, absolute profit increases (i.e., $\Delta \pi$ rather than $\Delta \pi / \pi$ ) are smallest for the least productive new exporter and increase monotonically with productivity, yielding an unambiguous ranking. In my robustness checks in Section 5.2, I show that with additional assumptions this result can be used to also make predictions about absolute changes in stock prices (as opposed to percentage changes).
} 
less affected than both continuing and exiting domestic firms. We should thus observe a positive difference in stock market returns between exporters and non-exporters upon the arrival of new information making an implementation of CUSFTA more likely.

So far, the discussion of profit changes has been in terms of present or future export status. But note that in the above model, the only firm-specific characteristic which determines a firm's export status is (labor) productivity. In addition, firm sales are directly proportional to productivity. This implies that in the data, we should observe differences in stock market returns across less and more productive, and smaller and larger firms, in addition to return differences between new and existing exporters, and non-exporting firms.

Using sales or productivity as the firm characteristic of interest also has the advantage that it provides more direct evidence on the reallocation mechanisms stipulated by models in the tradition of Melitz (2003). To see this, note that a model in which export status is exogenously given, or at least unrelated to firm size or productivity, would also predict that exporters should gain relative to non-exporters in reaction to U.S. tariff cuts. It would not, however, predict the ensuing productivity enhancing market share reallocation which is key to Melitz-type models. It would also not predict that more productive or larger firms gain relative to less productive or smaller firms. As such, relying on firm size or productivity allows for a more direct empirical test than relying on export status alone. ${ }^{10}$

\subsection{Discussion}

To what extent do these results carry over to alternative modeling frameworks? Chaney (2008) introduces income effects in an otherwise identical model by letting his utility function take a Cobb-Douglas form. This changes the magnitude of the profit responses but leaves the qualitative predictions of the previous section intact, as I demonstrate in the online appendix.

Another simplifying assumption of my baseline model is that wages are fixed which rules out factor market interactions. In contrast, such interactions are crucial for the results in Melitz (2003). While tariffs (or more generally, variable trade costs) are assumed to be symmetric in his model, the general intuition is clear. Lower foreign tariffs lead exporters to expand, putting upward pressure on domestic wages. Non-exporters thus face higher input costs but do not benefit from increased foreign markets access. In my context, U.S. tariff cuts would thus increase the profits of existing and new exporters relative to non-exporters (and of large vs small firms), similar to my baseline predictions.

A third simplification which is more critical for the previous results, especially with respect to domestic tariff reductions, is the assumption of a fixed number of potential entrants. For example, Melitz and Ottaviano (2008) present a version of their model with long-run entry in which the expected profits of new entrants are reduced to zero. If the discounting of future profits is low, the resulting equilibrium predictions of such a 'long-run' model for the profits of existing firms might be more relevant for stock price reactions then the predictions of 'short-run'

\footnotetext{
${ }^{10}$ Another problem with relying on export status is that it is hard in practice to distinguish between new exporters which started exporting because of U.S. tariff cuts and firms which took up exporting for other reasons (only the former conceptionally belong to the same group as existing exporters). See Section 4 for details.
} 
models such as Chaney (2008) which abstract from free entry. ${ }^{11}$

As I show in the online appendix, this does not matter for U.S. tariffs reductions because the 'short-run'and 'long-run'predictions of Melitz and Ottaviano (2008) are qualitatively identical. As in my baseline model, profits of new and existing exporters are predicted to increase relative to non-exporters. In contrast, allowing for long-run entry makes a qualitative difference to predictions with respect to domestic (Canadian) tariff reductions. Such reductions now lead to less entry, increasing the profits of the remaining firms. At the same time, better access to the Canadian market leads to increased entry of U.S. firms which also serve their domestic market. This makes it more difficult for Canadian exporters to sell there, lowering profits from exporting. The assumption of linear demand in Melitz and Ottaviano implies that the smaller and less productive non-exporters will see a stronger percentage increase in their domestic profits than exporters. They also do not suffer a reduction of their export profits. Thus, in the free-entry version of Melitz and Ottaviano (2008), Canadian tariff reductions favor those non-exporters in Canada which do not exit the market entirely (see the online appendix). ${ }^{12}$

To summarize, my discussion suggests that the predictions of my simple Chaney-type model with respect to export (i.e., U.S.) tariff reductions carry over to a range of heterogeneous firm models. In contrast, the relative effect of import (i.e., Canadian) tariff reductions on firms of different sizes and export status appears to be less robust, and might well be different in more general frameworks than the one presented here. Accordingly, it seems reasonable to place more emphasis on the results with respect to U.S. tariff cuts in the subsequent empirical analysis, although of course the estimated impact of Canadian tariff cuts might still be useful in discriminating between different versions of heterogeneous firm models. ${ }^{13}$

\section{Description of Events}

The Canadian federal election on 21 November 1988 provides a sharply defined event which can be exploited for event study evidence. ${ }^{14}$ CUSFTA was extremely contentious among the main

\footnotetext{
${ }^{11}$ Formally and using the same notation as in (1), $p_{i t}=\sum_{s=1}^{T} \frac{E\left(\bar{\pi}_{s r} \mid I_{t}\right)}{\left(1+e_{i}\right)^{s}}+\sum_{s=T+1}^{\infty} \frac{E\left(\bar{\pi}_{l r} \mid I_{t}\right)}{\left(1+e_{i}\right)^{s}}=$ $\frac{E\left(\bar{\pi}_{s r} \mid I_{t}\right)\left(\left(1+e_{i}\right)^{T}-1\right)}{\left(1+e_{i}\right)^{T} e_{i}}+\frac{E\left(\bar{\pi}_{l r} \mid I_{t}\right)}{\left(1+e_{i}\right)^{T} e_{i}}$ where $\bar{\pi}_{s r}$ and $\bar{\pi}_{l r}$ denote per-period profits in the short- and long-run. For fixed $T$ with $1 \leq T<\infty$, as $e_{i} \rightarrow \infty$ the short-run share of discounted profits in total discounted profits converges towards one. Likewise, as $e_{i} \rightarrow 0$, the share of short-run profits in total discounted profits goes to zero.

${ }^{12}$ More genereally, the result that exporters see their domestic profits fall by relatively less than non-exporters in response to import tariff reductions seems to be at least in part due to specific assumptions about demand and cost structures. In my baseline model, it is the presence of fixed costs which causes the relatively smaller fall of domestic profits for larger and more productive firms, and in Melitz and Ottaviano (2008) it is the assumption of linear demand. While the existing literature has not yet explored this issue, one could imagine a demand curve with more curvature than CES. This would imply a stronger percentage reaction in domestic profits for the more productive exporters and might reverse some of the above results. (With CES and in the absence of fixed cost, relative domestic profit changes are identical for firms with different levels of productivity.)

${ }^{13}$ Given their prominence in the literature, I focus on the evaluation of static heterogenous firm models with exogenously given firm productivity $(\gamma)$ throughout this paper. An interesting extension for future work would be to allow for interactions between stock prices and firm-level decisions. These could arise, for example, because stock prices impact on the availability of external finance and thus possibly on firms' investment decisions. See Burstein and Melitz (2011) for an exhaustive discussion of the properties of dynamic trade models with investment in innovation.

${ }^{14}$ The following discussion and selection of events is based on coverage in the Canadian press of the election campaign and the U.S.-Canadian negotiations regarding CUSFTA, Morck et al. (1998), Frizzell et al. (1989), Brander (1991), Johnston et al. (1992), and Thompson (1993). More specific citations follow below.
} 
Canadian political parties, with the governing Progressive Conservatives (who had negotiated the agreement) in favor, and broad sections of the main opposition parties (the Liberals and the New Democratic Party) opposed. Indeed, the Liberal Party's leader, John Turner, publicly vowed as late as October 1988 that he would dismantle CUSFTA in case of an election victory. The fate of CUSFTA thus depended on the election outcome on November 21.

At the same time, CUSFTA received an unprecedented amount of attention in the election campaign and was the single-most important issue in voters' minds. In opinion polls taken in the month before the election, over $80 \%$ of the electorate cite CUSFTA as the most important election issue (Frizzell et al., 1989). One would thus expect that market participants were aware of the key aspects of CUSFTA (including the extent of tariff cuts), and of the consequences a Conservative or Liberal election victory would have for CUSFTA's implementation.

Finally, the election outcome was highly uncertain. Given the particularities of the Canadian electoral system, the Conservatives needed a vote share of slightly more than $40 \%$ to obtain a parliamentary majority (Johnston et al., 1992). As late as the week before the vote on November 21, however, opinion polls showed Liberals and Conservatives head-to-head at $35 \%$ of the vote each. ${ }^{15}$ Such an outcome would have given Liberals and New Democrats a parliamentary majority and would have meant that CUSFTA would not be ratified. The turning point came only with the publication of three nationwide polls on November 19, the Saturday before the election. All three polls put the Conservatives at over $40 \%$ and clearly ahead of the Liberals. These predictions proved to be almost exactly correct, and on November 21 the Conservatives won the election with $43 \%$ of the popular vote, compared to $32 \%$ for the Liberal Party and $20 \%$ for the New Democrats.

Besides the election itself, I will look at three earlier events which also changed the likelihood of CUFTA's implementation. The second event is the reaching of an agreement on CUSFTA between Canada and the U.S. on Saturday, 3 October 1987. ${ }^{16}$ Negotiations had been difficult and were only brought to a successful conclusion hours before the deadline on October 3 imposed by the U.S. Congress' fast-track procedure. Thus, the reaching of an agreement was to some extent unexpected. At the same time, the last-minute negotiations were concerned with details of CUSFTA's dispute-settlement procedure, while the remaining key elements of the agreement (including the extent and timing of the tariff reductions) had already been in place. So market participants were probably aware of most of its consequences at this point and the relevant news when markets opened on October 5 was simply that an agreement had been reached, and not about the exact nature of tariff cuts.

The third event is again related to CUSFTA's ratification. On the morning of 20 July 1988, John Turner, the Liberal Party's leader, announced at a press conference that he had instructed the Liberal majority in the Senate to block the ratification of CUSFTA until a general election, which was expected to be called within the next months. This was seen by many as a move to revive the electoral prospects of his party which was trailing in the opinion polls (Johnston et al., 1992). By delaying the ratification, John Turner effectively turned the general election

\footnotetext{
${ }^{15}$ All opinion polls quoted in this section are taken from Frizzell et al. (1989).

${ }^{16}$ The information in this paragraph is based on the extensive coverage of the negotations in the Canadian newspaper The Globe and Mail from 5 October 1987. Also see Thompson (1993).
} 
into a referendum on CUSFTA. This move destroyed any hopes for a quick ratification and even raised the possibility that CUSFTA might not be implemented at all, given the hostility of Liberals and New Democrats to the agreement.

Finally, I also use a particularly dramatic change in opinion polls in the run-up to the election. After it had become clear that the Senate would not ratify CUSFTA, prime minister Brian Mulroney called a general election on October 1. In the initial phase of the election campaign, the Conservatives had a clear lead in the opinion polls. An important turning point came with the only two televised debates between the main parties' leaders on October 24 and 25. Against expectations, John Turner emerged as the clear winner from these debates and electoral fortunes started to change. The most dramatic and unexpected event in this phase of the campaign was the publication of a Gallup poll on the morning of November 7, putting the Liberals at $43 \%$ of the vote, compared to only $31 \%$ for the Conservatives and $22 \%$ for the New Democrats. While opinion polls had been gradually shifting since the debates, this presented a massive increase in support for John Turner's party and for the first time made a Liberal victory look likely (Brander (1991); Frizzell et al. (1989)). In response, the Conservatives undertook a radical overhaul of their campaign strategy, enabling them to catch up in the opinion polls again (Frizzell et al., 1989). However, it was only with the above-mentioned publication of three nationwide opinion polls on November 19 that it became clear that the Conservatives would win.

To summarize, my principal event is the election day (November 21) and the first trading day after the election (November 22). While markets could only react to the election results on November 22, the publication of the opinion polls on November 19 had already made a Conservative victory very likely. The remaining three events are less important shifts in the likelihood of CUSFTA's implementation but are useful as robustness checks. In particular, events three and four imply a decrease in the likelihood of ratification and should lead to opposite stock market reactions from the election event. Events two and three present changes in the probability of CUSFTA's implementation which are unrelated to the election outcome. They will provide additional evidence that market reactions were indeed due to CUSFTA rather than a Conservative election victory.

\section{Methodology, Data and Descriptive Statistics}

Methodology. Testing the theoretical predictions from Section 2 requires a model of "normal" stock returns which adjusts for differences in risk and other characteristics of stocks. A standard approach in the literature is to use the so-called market model which relates the return on security $i$ at time $t$ to a stock-specific constant and the return on the market portfolio, $R_{m t}$ (Campbell et al., 1989; Binder, 1998):

$$
r_{i t}=\alpha_{i}+\beta_{i} R_{m t}+\varepsilon_{i t}
$$

This approach controls for differences in average returns across stocks $\left(\alpha_{i}\right)$, a stock's (nondiversifiable) risk as measured by $\beta_{i}$ and movements in the market portfolio. The error term 
$\varepsilon_{i t}$ captures "abnormal" returns which in the present context could be caused by the arrival of unexpected news about the implementation of CUSFTA. ${ }^{17}$

A straightforward way to measure abnormal returns related to CUSFTA is to directly model the error term in equation (6) according to the theoretical discussion from Section 2:

$$
r_{i t}=\alpha_{i}+\beta_{i} R_{m t}+\sum_{e=1}^{E} d_{e t}\left(d_{j}+\gamma_{1 e} d_{i x}\right)+\eta_{i t}
$$

where the $d_{e t}$ are a set of dummy variables, each taking a value of one for one particular day during event window $E$. The $d_{j}$ are industry fixed effects, and $d_{i x}$ is a variable classifying firms into groups in accordance with the predictions from Section 2. For example, in my baseline model in Section 2.2, it is related to the productivity level $\phi_{S}$ separating non-exporters from firms which start exporting in response to U.S. tariff cuts, and to the productivity level $\phi_{X}$ separating exporter and non-exporters in the case of Canadian tariff cuts. The theoretical prediction is that firms with productivity below these levels should lose relative to firms with productivity levels above. As discussed, these levels are not directly observable in the data and I will use various proxies for $d_{i x}$ based on firm sales, employment, productivity and export status (see below for details).

Equation (7) is estimated on a sample containing both pre-event and event data (see below for details). As discussed by Binder (1998), and as I show in robustness checks reported in the online appendix, this one-step approach is equivalent to the traditional two-step procedure of first estimating the market model parameters $\alpha_{i}$ and $\beta_{i}$ on pre-event data only (the so-called estimation period), computing abnormal returns as prediction errors of the market model during the event period, and then regressing these abnormal returns on industry fixed effects and the proxy for $d_{i x}$. A key advantage of (7) is that the modeling of heteroscedasticity and crosssectional dependence in abnormal returns is more straightforward and can be done via an appropriate clustering of standard errors in a standard OLS regression framework. ${ }^{18}$

The coefficient estimate $\hat{\gamma}_{1 e}$ represents the average abnormal return difference for firms with different values for $d_{i x}$ on event day $e$, after controlling for industry fixed effects. If an event takes place over more than one day (as is the case for my main election event), I calculate cumulative average abnormal return differences (CAARs), defined as $C A A R_{E}=\sum_{e=1}^{E} \hat{\gamma}_{1 e}$.

As already discussed, one concern with (7) is that my main event (the general election) not only changed the likelihood of CUSFTA's implementation but also expectations about other policies. For example, a conservative victory might have been seen as advantageous for firms which are larger, more productive, or are present or likely future exporters. I thus make use of the sectoral variation in tariff cuts implemented under CUSFTA by estimating:

\footnotetext{
${ }^{17}$ This is the part of stock returns I focused on in Section 2. Note that the dividend discount model can easily be extended to generate a "normal" rate of return in addition to event-induced (abnormal) returns by introducing expected dividend/profit growth.

${ }^{18}$ Throughout this paper, I cluster standard errors by trading day (there are approximately 300 trading days in my estimation and event periods, depending on the particular specification and event in question). This allows for both heteroscedasticity and arbitrary cross-sectional dependence in the residual $\eta_{i t}$ for a given day, and consistent with the maintained assumption of market efficiency - restricts intertemporal correlations to zero.
} 


$$
r_{i t}=\alpha_{i}+\beta_{i} R_{m t}+\sum_{e=1}^{E} d_{e t}\left(d_{j}+\gamma_{1 e} d_{i x}+\gamma_{2 e} d_{i x} d t_{C A N, j}+\gamma_{3 e} d_{i x} d t_{U S, j}\right)+\eta_{i t}
$$

where $d t_{C A N, j}$ and $d t_{U S, j}$ denote Canadian and U.S. tariff cuts in industry $j$ between 1988 and 1996, respectively. ${ }^{19}$ Recall from the earlier discussion that larger, more productive firms should benefit more from higher U.S. tariff cuts than smaller, less productive firms (i.e., $\gamma_{3 e}<0$, given that higher reductions imply a more negative $d t$ ). In the model from Section 2.2 this is also true for Canadian tariff cuts (i.e., $\gamma_{2 e}$ is also expected to be negative), although I noted that this prediction might not survive in other heterogeneous firm models.

Introducing variation in tariff cuts into the modeling of abnormal returns means I only require the weaker identifying assumption that the differential impact of a Conservative victory on firms of different sizes, productivity levels and export status does not vary systematically with the extent of U.S. or Canadian tariff cuts. If Conservative policies simply benefited larger firms more than smaller firms, this effect will be captured in the $d_{i x}$ dummies. Likewise, identification is still assured if a Conservative election win benefited certain sectors more than others but not differentially so across firms of different sizes, productivity and export status - any such effect will be captured by the industry fixed effects in (8). ${ }^{20}$

Data. Estimation of (7) and (8) requires data on daily returns on individual stocks and the market portfolio, the tariff cuts implemented under CUSFTA, and information about firm size, productivity and export status. For comparability with the existing literature and because of the availability of information on tariff cuts, I focus my analysis on firms in the manufacturing sector. Because of the tradability of its output, this is also the sector most directly affected by CUSFTA and the one that corresponds best to the theoretical model from Section 2.

I use daily stock returns from Datastream for all Canadian manufacturing firms listed on one or several Canadian or U.S. stock exchanges for which I have at least one year of return data prior to the event studied. This is the standard length in the event study literature for the pre-event window used to estimate the market model's parameters (see Binder (1998)). I also follow a large part of the literature by using the value-weighted CRSP portfolio as a proxy for the market portfolio. ${ }^{21}$

Tariff data are from Trefler (2004) who provides U.S. and Canadian ad-valorem tariffs for manufacturing industries at the four-digit level of the Canadian Standard Industrial Classication

\footnotetext{
${ }^{19} 1996$ is the last year for which I have tariff data. Manufacturing tariffs were phased out linearly over a period of up to ten years under CUSFTA and were close to zero in 1996 (see Trefler, 2004).

${ }^{20}$ Trefler (2004) and other authors have also argued that tariff cuts under CUSFTA were exogenous. CUSFTA was a clearly defined policy experiment in the sense that it was neither introduced in response to a macroeconomic shock nor part of a larger package of reforms. It was also a free trade agreement under which tariffs were reduced to zero. This meant that the extent of tariff cuts was exclusively determined by the initial level of tariffs in each sector, so that there was no scope for policymakers to retain tariffs for sectors in need of continued protection. Indeed, Trefler (2004) experiments with different instrumental variable strategies and, using the same tariff data as in this paper, finds no evidence for endogeneity problems in the corresponding Hausman tests.

${ }^{21}$ I obtain CRSP portfolio returns from the Wharton Research Data Services (wrds.wharton.upenn.edu). The CRSP portfolio should be less susceptible to endogeneity concerns, given that the firms in my sample represent a large share of the overall market capitalization in purely Canadian-based portfolios such as the S\&P/TSX Composite Index. Also note that CRSP contains a number of Canadian firms quoted on U.S. stock exchanges (but which only account for a small fraction of overall U.S. market capitalization).
} 
of 1980. I map these tariffs into the industry classification used by Datastream (the Industry Classification Benchmark, ICB) which sorts manufacturing firms into 20 broad industries. ${ }^{22}$

Among the required firm-level variables, data availability is best for firm sales, followed by (labor) productivity and information on export status. As discussed, using firm size (and productivity) also has the advantage of providing more direct evidence on the reallocation mechanism highlighted by models such as Melitz (2003), and helps addressing the difficulty of identifying new exporters in the data. To illustrate this last point, recall from Section 2 that firms which start exporting in response to U.S. tariff reductions belong conceptually to the same group of firms as exporters - both observe profit increases relative to firms which never export. In the present case, new exporters accounted for a large fraction of all exporters. For example, Baldwin and $\mathrm{Gu}$ (2003) report that the fraction of exporters among manufacturing firms increased by almost $70 \%$ during the implementation period of CUSFTA. On the other hand, it is impossible to know whether all of these firms started exporting because of CUSFTA or would have taken up exporting anyway. Thus, focusing on actual export status risks selecting an inappropriate mix of firms for treatment and control groups.

In my baseline specification, I thus proxy the key regressor $d_{i x}$ in (7) and (8) by the log of the value of a firm's sales in 1988. Using a continuous measure avoids taking a stance on the exact cutoff value of sales which divides firms in an industry into 'winners' and 'losers' from trade liberalization. The use of log sales also facilitates the inclusion of a number of binary control variables in later robustness checks which are often highly correlated with firm sales (such as multinational status). In extensive robustness checks in Section 5.2, I compare my baseline results with a number of alternative measures for $d_{i x}$, including employment, labor productivity, and information on actual actual export status. In practice, these different measures of firm heterogeneity yield qualitatively very similar results to my baseline specification. This is probably not surprising, given that the strong positive correlation between firm size (as measured by sales or employment), productivity and export status is one of the most robust empirical findings in the literature on exporter premia (e.g., Bernard and Jensen, 1999).

Data on firm sales, employment, labor productivity and exports are also from Datastream. I complement this information with data from Compustat North America whenever Datastream has missing values. This yields a sample of 247 publicly traded Canadian companies with primary activities in manufacturing for which I have information on sales and stock prices. When using my alternative measures for $d_{i x}$, I have to rely on a smaller sample of 210 firms for employment and labor productivity, and on a sample of 54 firms for export status information.

Descriptive Statistics and Figures. Table 1 provides summary statistics for the number of firms, firm sales and tariff reductions by industry. I note two main points. First, tariff cuts show substantial sectoral variation despite the relatively aggregate industry classification used here (columns 6-7). Canadian tariff cuts range from sectors which basically enjoyed free trade

\footnotetext{
${ }^{22}$ See Table 3 for a list of these industries. I use detailed descriptions of individual industries obtained from Datastream and Statistics Canada to construct a mapping from Trefler's 213 Canadian Standard Industrial Classification (CANSIC) industries to the 20 ICB industries used in this paper. This mapping was unique in $90 \%$ of cases, in the sense that each CANSIC industry could be mapped into one ICB industry only. I aggregate the tariff data to the ICB level by taking weighted averages across all CANSIC categories mapping into an ICB industry, using 1988 output shares of CANSIC industries as weights. Output data are also from Trefler (2004).
} 
before CUSFTA to over $25 \%$ for "Beverages". U.S. tariff cuts are lower on average but still show strong sectoral differences, with tariff cuts between $0 \%$ and close to $10 \%$.

Second, my focus on publicly traded firms means that my sample is biased towards larger manufacturing firms (see columns 3-5). This size bias is of course an unavoidable feature of using stock market data for testing economic theories. Nevertheless, there are reasons to believe that the size variation in my data will be informative about between-firm differences within industries. ${ }^{23}$ First, there is a strong variation in sales within industries, ranging from small startups with sales of less than a million Canadian dollars to big corporations with several billion dollars in turnover. This somewhat alleviates the concern that my sample is unrepresentative of smaller firms. Second, the export incidence among Canadian manufacturing firms was much lower in 1988 than nowadays, implying a substantial number of non-exporters even among larger manufacturing firms. ${ }^{24}$ Third, and most importantly, the most probable effect of any remaining sample bias will be to make it less likely to observe statistically significant differences in stock market returns between small and large firms in response to news about CUSFTA. To see this, note that the sample bias towards larger firms implies that even the smaller firms in my sample are relatively large compared to the average Canadian manufacturing firm. Thus, given the well-known positive correlation between firm size and export status, it seems likely that the small(er) firms included in my sample are closer to becoming exporters in the future and should benefit more from trade liberalization than the small firms excluded from my sample. As a consequence, my results will tend to underestimate the true differential impact of tariff cuts on large vs small firms. But given that below I do find statistically significantly higher returns for larger firms compared to smaller firms within the same industry (at least in the case of U.S. tariff cuts), none of my qualitative conclusions in the following should be affected by the specific sample composition that arises from focusing on publicly traded firms.

Figure 1 takes a closer look at the data by visualizing the difference-in-differences identification strategy embodied in my key specification, equation (8). I focus on my main event, the general election on November 21. However, to fully appreciate the high degree of uncertainty surrounding the election outcome, it is useful to look at a slightly longer window, starting a week before the televised debates between the main parties' leaders on October 24 and 25. For this period, I plot cumulative average return (CAR) differences between large and small firms, defined here simply as firms with sales above and below the 50th percentile in each industry, respectively. ${ }^{25}$ I plot CAR differences for two groups of firms. Those belonging to the $50 \%$ of

\footnotetext{
${ }^{23}$ Within-industry size variation is the type of variation relevant for my comparison of stock returns of different types of firms while controlling for industry fixed effects. But note that in terms of overall economic activity, my sample is also quite representative of Canadian manufacturing, with firms in my sample accounting for C $\$ 186$ billion or approximately two thirds of total Canadian manufacturing sales in 1988.

${ }^{24}$ Baldwin and $\mathrm{Gu}$ (2003, Table 1) report that in 1984, the last year for which they have data before the implementation of CUSFTA in 1989, only $14 \%$ of manufacturing plants exported. This rises to $31 \%$ when looking at plants surveyed for the Annual Surveys of Manufactures (ASM) which are substantially larger than the average Canadian manufacturing plant and thus correspond more closely to my sample of publicly traded firms. As mentioned above, I only observe export status for around $20 \%$ of my firms. But for the 54 firm for which I observe export status, the fraction of non-exporters is still $30 \%$.

${ }^{25}$ The cumulative average return of a group of stocks $G$ between $t_{1}$ and $t_{2}$ is defined as $C A R_{t_{1} t_{2}}=\sum_{s=t_{1}}^{t_{2}}$ $\frac{1}{N_{G}} \sum_{i \epsilon G} r_{i s}$, where $r_{i s}$ is the return of stock $i$ at time $s$ and $N_{G}$ is the number of stocks in group $G$. The difference in $C A R s$ between exporters and non-exporters in high tariff cut industries, for example, is then simply
} 
industries with the highest U.S. tariff cuts implemented under CUSFTA, and those with the $50 \%$ lowest tariff cuts. ${ }^{26}$ CAR differences are normalized to zero for both groups one week before the televised debates on October 24 and 25.

The figure clearly shows a sharp divergence in the CAR differences between high- and lowtariff cut industries in the aftermath of the debates, as the Liberal Party's standing in the polls improved. This divergence is particularly dramatic on the day of the publication of the Gallup poll, November 7. Also visible in the graph is the stabilization in CAR differences between large and small firms, and between high- and low-tariff cut industries, as the Conservatives caught up in the polls again. (The week beginning November 14 brought a couple of opinion polls showing the parties head-to-head.) Finally, the difference between high- and low-tariff cut industries narrows sharply on election day, November 21, and to a lesser extent on November 22. Thus, this graphic analysis provides some first suggestive evidence that stock prices reacted to news about CUSFTA in a way consistent with the predictions of heterogeneous firm models.

\section{Results}

\subsection{Baseline Results}

I now turn to the estimation of the baseline equations (7) and (8). Table 2 presents results for my main event on November 21 and 22. Here and in the following robustness checks (Section 5.2 ), I focus on the sign of my coefficient estimates and defer a discussion of their magnitude and economic significance to Section 5.3.

Column 1 of Table 2 reports results based on specification (7), using log sales as my proxy for the key regressor $d_{i x}$. The results indicate that larger firms experienced significantly higher abnormal returns - about 0.3 percentage points per log point of sales. This is consistent with the predictions of my baseline model from Section 2.2. As already mentioned, this result could also capture a more positive impact of a Conservative election victory on larger firms.

In column 2, I include the tariff interaction terms as in (8). As predicted, the sign on the U.S. tariff interaction is negative and significant. Thus, larger firms observed stronger positive abnormal returns in sectors with larger U.S. tariff cuts. This is strongly supportive of a Melitztype story in which larger firms benefit from increased export opportunities.

Larger firms also benefited from higher Canadian tariff cuts relative to smaller firms. This is consistent with my baseline model as well as with Chaney (2008) and the 'short-run' version of Melitz and Ottaviano (2008). While this effect is highly statistically significant, its absolute magnitude is much smaller than the effect of U.S. tariff reductions, even after taking into account that Canadian tariff cuts were on average twice as large as U.S. tariff cuts (see Table 3).

\footnotetext{
$C A R_{X h i g h}-C A R_{N X h i g h}$. Using abnormal rather than simple returns yields a similar picture.

${ }^{26}$ I focus on U.S. tariff cuts since the theoretical predictions are unambiguous here. Graphs using Canadian tariff cuts yield a broadly similar picture.
} 


\subsection{Robustness Checks}

I now examine the robustness of my baseline results presented in Table 2. I focus on the most important robustness checks here, and report additional results in the online appendix. ${ }^{27}$

Alternative Measures of Firm Heterogeneity I: Sales-Based Measures. I first experiment with a number of alternative proxies for my key regressor $d_{i x}$. Table 3 shows results for several indicators which are also based on firm sales but which now take a binary form, classifying a firm as benefitting from trade liberalization if its sales exceed a given industry-specific threshold value.

In columns 1 and 2 of Table 3, I classify firms as 'large' $\left(d_{i x}=1\right)$ if their sales are above the 30th percentile of an industry's sales distribution. This threshold was chosen to match the fraction of exporters for the subsample of 54 firms for which I observe exports in 1988. Using this threshold yields qualitatively identical results to my baseline specification. Larger firms experienced abnormal returns which were 0.9 percentage points higher than those of smaller firms, with the difference being highly statistically significant (column 1). In column 2, I include the tariff interaction terms which are again negative and significant for both U.S. and Canadian tariffs. The abnormal return difference between large and small firms increases by 0.9 percentage points for each percentage point in U.S. tariff reductions, and by 0.2 percentage points for each percentage point in Canadian tariff reductions.

The 30th percentile threshold is my preferred binary proxy for $d_{i x}$ but I also present results for cutoffs based on more extreme assumptions, ranging from the 20th to the 80th percentile of industry-specific sales distributions. The 20th percentile threshold rule is again derived from the fraction of exporting firms in the subsample with export information, but this time also classifies firms as exporters if they have positive export sales in either 1988 or in any year of CUSFTA's implementation period (1989-1997). Implicitly, this assumes that all of these new exporters entered the export market because of CUSFTA. Since this is a strong assumption, the 20th percentile threshold should be seen as an upper bound on the true fraction of pre- and post-CUSFTA exporters. At the other end of the range of the thresholds used in Table 3 is the 80th percentile cutoff (columns 9-10), which classifies only $20 \%$ of firms as new or existing exporters. This figure corresponds to the fraction of exporters among Canadian manufacturing plants in the pre-CUSFTA period reported in Baldwin and Gu (2003). Since most of these units of production are substantially smaller than the publicly traded firms in my sample, and since firm and plant size are strongly correlated with present and future export status, the 80th percent threshold clearly represents a lower bound on the number of firms likely to benefit from CUSFTA. Finally, I use information on the fraction of exporters per Canadian industry published in Statistics Canada (2000) to introduce sectoral variation in the percentile threshold.

\footnotetext{
${ }^{27}$ The online appendix presents results for: 1) changes in the length of the event period; 2) using a two-step estimation procedure where I calculate abnormal returns in a first step and use them as the dependent variable in a second step; 3) using Fama-French portfolios in the abnormal returns regressions to control for systematic return differences across firms related to size; 4) using returns rather than abnormal returns; 5) using log-returns as the dependent variable; 6) removing outliers and changing the sample composition in different ways; 7) using alternative tariff measures which only use the part of bilateral U.S. and Canadian tariff reductions which exceeds changes in the tariffs between these countries and the rest of the world; and 8) realized ex-post changes in profit margins.
} 
As discussed above, it is likely that exporting is more common among the firms in my sample. Thus, I normalize the average fraction of new and existing exporters across industries to equal $30 \%$ as in my binary baseline specification, but preserve the sectoral variation present in the Statistics Canada data. This yields thresholds for $d_{i x}$ ranging from the 90th percentile of the sales distribution in Media to the 5th percentile in Technology Hardware and Equipment (i.e., the fraction of firms with $d_{i x}=1$ varies between $10 \%$ and $95 \%$ ).

The results reported in columns 3-12 are qualitatively similar to my baseline specification with the exception of the results based on the 20th percentile threshold, where the Canadian tariff interaction is positive (albeit small and only marginally significant). The magnitude of the coefficient estimates is also relatively stable across specifications, with most estimates in the range -0.7 to -1.3 for the U.S. tariff cut interaction and around -0.05 to -0.20 for the Canadian tariff interaction variable. Clearly, the pattern that larger firms gained relative to smaller firms, and more so in sectors with higher U.S. tariff cuts is robust to a wide range of sales-based proxies for $d_{i x}$. The results related to Canadian tariff reductions also mostly confirm my baseline results, although the magnitude of the reported effects is again smaller than for U.S. tariff cuts.

Alternative Measures of Firm Heterogeneity II: Actual Export Status. In Table 4, I make use of the more limited information on export sales available in my data. In columns 1-4, I reestimate equations (7) and (8) for the 54 firms for which I observe exports. ${ }^{28}$ In columns 1-2, I set $d_{i x}=1$ for firms which report positive export sales in 1988. In columns 3 to 4 , I set $d_{i x}=1$ for firms which report positive exports in either 1988 or during at least one year of CUSFTA's implementation period (1989-1997). As described above, these classifications yield exporter shares of $70 \%$ and $80 \%$, respectively. The results for these specifications are again qualitatively similar to before, with exporters experiencing higher abnormal returns than non-exporters, with the difference being stronger in sectors with larger U.S. tariff cuts.

The small size of these two subsamples precludes the use of industry fixed effects. Together with the change in sample structure, this makes a direct comparison of coefficient magnitudes with Table 3 difficult. I thus reestimate equations (7) and (8) for this smaller sample, excluding industry fixed effects and using the two binary proxies for $d_{i x}$ based on sales thresholds at the 20th and 30th percentile. The results in columns 5-8 are very similar to columns 1-4 which use export-based proxies for $d_{i x}$. Note that in columns 1-4, Canadian tariff cuts are now estimated to have led to lower relative returns of exporters, in contrast to most of the results from Table 2 and 3 (where larger firms gained relative to smaller firms). However, this result is obtained both when using the export status proxy for $d_{i x}$ and when using the binary proxies based on sales, again with almost identical coefficient magnitudes. Thus, proxies for $d_{i x}$ based on sales and export information yield very similar results. Results using log sales for this smaller sample are harder to compare quantitatively to the results for export status because of the different functional form used. But as seen in columns 9 and 10, results are again qualitatively similar.

\footnotetext{
${ }^{28}$ I only observe the value of total exports, not the value of exports to the United States. However, given that over $80 \%$ of Canadian exports between 1988-1997 went to the U.S., any firm that exported during this period is very likely to have served the U.S. market.
} 


\section{Alternative Measures of Firm Heterogeneity III: Employment and Labor Produc-}

tivity. I also experiment with proxies for $d_{i x}$ based on employment and labor productivity. For each of these variables, I construct proxies in the same way as for my preferred measures based on sales. That is, I first use the log of labor productivity or employment. I then classify a firm as likely to benefit from trade liberalization $\left(d_{i x}=1\right)$ if its employment or labor productivity is higher than the 30th percentile of that firm's industry. One downside of using these additional proxy variables is that information about firm-level employment is only available for 210 firms, implying a $15 \%$ reduction in sample size. ${ }^{29}$ In any case, the results shown in Table 5 are qualitatively similar to my earlier results. The coefficient estimates based on the two employment proxies are also quantitatively very close to the comparable proxies based on firm sales. The estimates based on labor productivity are slightly higher with respect to U.S. tariff cuts and close to zero and insignificant for Canadian tariff cuts.

Event-Induced Changes in Market Model Parameters and Discount Rates. A standard concern in the event study literature is that the market model parameters $\left(\alpha_{i}\right.$ and $\left.\beta_{i}\right)$ are not stable over time but are changed by the event itself. This will lead to biased estimates of abnormal returns and could also bias my parameters of interest (the $\gamma^{\prime} s$ in equation 8). This will be the case if changes in the market model parameters are systematically correlated with my measures of firm heterogeneity (size, productivity, export status) and/or tariff cuts.

Thus, I re-estimate my baseline specification (8) but extend the sample period to the end of December 1988 and allow the $\beta_{i}$ to change with the election event: ${ }^{30}$

$r_{i t}=\alpha_{i}+\beta_{i} R_{m t}+d_{\text {post }}\left(\alpha_{i p}+\beta_{i p} R_{m t}\right)+\sum_{e=1}^{E} d_{e t}\left(d_{j}+\gamma_{1 e} d_{i x}+\gamma_{2 e} d_{i x} d \tau_{C A N, j}+\gamma_{3 e} d_{i x} d \tau_{U S, j}\right)+\eta_{i t}$

where $d_{\text {post }}$ is a dummy variable taking the value of one for dates on or after November 21, 1988. Columns 1-2 of Table 6 presents the corresponding results. In column 1, I only allow the $\beta_{i}$ to change with the event whereas in column 2 , the $\alpha_{i}$ are allowed to change as well. Results in column 1 are basically identical to my baseline estimation, while allowing $\alpha_{i}$ to vary only results in minor changes in parameter estimates.

A related concern is that the election event could have changed a stock's expected return ( $e_{i}$ in the notation of Section 2, equation 1) and thus the appropriate discount rate for future profits, in addition to future profits themselves $\left(E\left(\pi_{i} \mid I_{t}\right)\right)$. Indeed, there is a large literature on the relative importance of cash flow and discount rate news in explaining stock returns (see Cochrane (2011) and Koijen and van Nieuwerburgh (2011) for recent surveys). While the more recent literature finds a larger role for cash flows, it still attributes up to $50 \%$ of stock price variation to unexpected changes in discount rates (e.g., Chen, Da and Zhao (2013)). Discount rate changes around my event dates are of course not directly observable, making it difficult to

\footnotetext{
${ }^{29}$ Information on intermediate input use is only available for a small minority of firms, so that I define labor productivity as sales per employee rather than as value added per employee. Likewise, information on capital stocks and investment is also very incomplete, preventing the use of total factor productivity.

${ }^{30}$ Here and in the remainder of the paper, I focus on my main specification (8) for the sake of brevity. Results for specification (7) are available upon request. The general pattern of the omitted results is consistent with the predictions discussed in Section 2 and the baseline results in Table 2.
} 
evaluate their role in explaining my results. However, two observations make it likely that they were not of first order importance.

First, any changes in discount rates would have to be correlated with my firm performance measures and tariff cuts. That is, discount rate changes would need to impact the return differences between large and small firms, and the impact would need to be stronger in sectors with larger tariff cuts. This is a much stronger requirement than a simple change in discount rates in response to my events.

Second, my previous results on changes in stocks' market model parameters provide some tentative evidence that changes in discount rates were not quantitatively important in my setting. To see this, note that the market model provides a natural benchmark for what the expected rate of return of a stock should be: $e_{i t}=E\left(r_{i t}\right)=\alpha_{i}+\beta_{i} E\left(R_{m t}\right){ }^{31}$

In a first step, I use my estimates for changes in $\alpha_{i}$ and $\beta_{i}$ from the previous regresssions to identify stocks with statistically significant changes in $e_{i t} .{ }^{32}$ This is the case for only about $15 \%$ of stocks in my sample, indicating that significant changes in discount rates are not common. These changes are also essentially uncorrelated with my measures of firm heterogeneity or tariff reductions. ${ }^{33}$ Secondly, I drop all stocks with significant estimated changes in $e_{i t}$ from my sample, and re-estimate my baseline equation (column 3). Finally, in column 4, I directly control for the estimated change in $e_{i t}$ in my market model regression rather than dropping stocks. ${ }^{34}$ Again, the results in these last two columns are very similar to my baseline estimates, indicating that changes in expected returns are not the main drivers of my earlier results.

Intermediate Input Tariffs and Multinational Status. In Table 7, I consider two potential alternative explanations for my results. First, tariff reductions under CUSFTA might partially pick up the impact of intermediate input tariff reductions. As Amiti and Konings (2007) have shown for Indonesia, lower tariffs on imported intermediate inputs can lead to significant increases in firm-level productivity. In their sample, these gains were particularly pronounced among firms importing intermediates directly. In the present case, Canadian tariff reductions lowered the costs of inputs imported from the U.S. This should have increased profits of Canadian firms and potentially more so for importers. If importers are among the largest firms in each industry (as the empirical literature on firm-level imports suggests), my interactions of tariff cuts and firm sales could simply be picking up the effect of cheaper imported

\footnotetext{
${ }^{31}$ An explicit and full integration of the trade models and the dividend discount model from Section 2 with an equilibrium model of asset prices is beyond the scope of this paper. But note that my expression for $e_{i}$ follows naturally from just such an equilibrium model (the Capital Asset Pricing Model or CAPM). The CAPM states that $e_{i t}=r_{f}+\beta_{i}\left(E\left(R_{m t}\right)-r_{f}\right)$, where $r_{f}$ is the risk-free rate of return, $\beta_{i}$ measures an asset's sensitivity to non-diversifiable (or market) risk, and $R_{m t}$ is the return on the market portfolio. Thus, the market model nests the CAPM equation as a special case with $\alpha_{i}=\left(1-\beta_{i}\right) r_{f}$.

${ }^{32}$ These are stocks for which the following equality is rejected at the $5 \%$ level: $\alpha_{i}+\alpha_{i p}+\left(\beta_{i}+\beta_{i p}\right) R_{m p}=$ $\alpha_{i}+\beta_{i} R_{m b}$, where $R_{m b}$ and $R_{m p}$ are the average pre- and post-election returns on the market portfolio.

${ }^{33}$ The correlation coefficient between log-sales and the difference in expected returns $\left(e_{i t, p o s t}-e_{i t, p r e}\right)$ is 0.061 . The correlation coefficient between $\log$-sales and the percentage change in expected returns $\left(e_{i t, p o s t} / e_{i t, p r e}\right)$ is 0.066 .

${ }^{34}$ In the notation of equation (2), differences in event-induced (or abnormal) returns across firms in the presence of changes in $e_{i}$ are $r_{E, i}-r_{E, i^{\prime}}=\frac{E\left(\pi_{i} \mid I_{t+\varepsilon}\right)}{E\left(\pi_{i} \mid I_{t}\right)} \frac{e_{i t}}{e_{i t+\varepsilon}}-\frac{E\left(\pi_{i^{\prime}} \mid I_{t+\varepsilon}\right)}{E\left(\pi_{i^{\prime}} \mid I_{t}\right)} \frac{e_{i^{\prime} t}}{e_{i^{\prime} t+\varepsilon}}$. Disregarding second-order terms, this is approximately equal to $\left(\frac{E\left(\pi_{i} \mid I_{t+\varepsilon}\right)}{E\left(\pi_{i} \mid I_{t}\right)}-\frac{E\left(\pi_{i^{\prime}} \mid I_{t+\varepsilon}\right)}{E\left(\pi_{i^{\prime}} \mid I_{t}\right)}\right)+\left(\frac{e_{i t}}{e_{i t+\varepsilon}}-\frac{e_{i^{\prime} t}}{e_{i^{\prime} t+\varepsilon}}\right)$. This motivates my inclusion of $\frac{e_{i t}}{e_{i t+\varepsilon}}$ as an additional regressor in the abnormal return part of (8).
} 
intermediates. $^{35}$

To control for this possibility, I rerun my baseline specification but include an additional interaction term between reductions in Canadian intermediate input tariffs and log sales. I construct input tariffs by using the Canadian input-output matrix together with the information on Canadian tariff reductions used previously. As is standard in the literature (see Amiti and Konings (2007) or Topalova and Khandelwal (2011)), I construct the input tariff for industry $j$ as the weighted average of the Canadian tariffs of all industries $k$ supplying this industry. That is, input_tariff $f_{j}=\sum_{k} w_{k j} \times$ tarif $f_{k}$, where $w_{k j}$ is the cost share of industry $k$ in the production of goods in industry $j$ in 1988. I construct input tariffs for 1988 and 1996 and use the difference as my measure of intermediate input tariff reductions due to CUSFTA.

A second potential omitted variable is multinational status. Given that multinational enterprises (MNEs) tend to be among the largest firms in all sectors, my log-sales proxy is likely to be positively correlated with MNE status. Again, my results might thus pick up a differential impact of tariff reductions on MNEs and non-MNEs. Fortunately, my data contain information on foreign affiliate sales and assets for about $80 \%$ of firms in my baseline sample, so that I can separately identify the impact of firm size (log sales) and MNE status. ${ }^{36}$

Column 1 in Table 10 shows results controlling for intermediate input tariffs, column 2 for MNE status, and column 3 includes both control variables jointly. As expected, stronger reductions in input tariffs further increase the abnormal return difference between large and small firms. In contrast, MNE status lowers abnormal returns in sectors with higher tariff reductions, although the effect is only statistically and economically significant for U.S. tariff cuts. This is consistent with, for example, a tariff-jumping motive for foreign direct investment, in which Canadian MNEs establish U.S. production sites to avoid export duties on their sales there. As U.S. tariffs are eliminated, the value of this local presence is diminished.

Finally, note that the results relating to U.S. tariff cuts are robust to the inclusion of the above control variables, and coefficient magnitudes are similar to my baseline specification. In contrast, the Canadian tariff interaction term becomes insignificant or even slighlty positive once I control for MNE status. This reinforces the impression from the previous robustness checks that the findings related to Canadian tariff cuts are less robust to changes in the estimation equation. At the same time, the results show that Canadian tariff cuts did have a substantial impact on stock returns via the implied change in intermediate input tariffs. ${ }^{37}$

Placebo Checks. I now turn to settings for which I would not expect to find significant abnormal return differences between large and small firms, nor a strong variation of these differences across industries with high and low tariff cuts. Specifically, I estimate specification

\footnotetext{
${ }^{35}$ This is particularly true given the positive correlation between the (output) tariffs used in my regressions and intermediate input tariffs. In my sample, the correlation of Canadian intermediate input tariffs with Canadian output tariffs is $28 \%$, and the correlation with U.S. output tariffs is $47 \%$. See below for how intermediate input tariffs were constructed.

${ }^{36} \mathrm{~A}$ firm is classified as an MNE if it either reports positive local affiliate sales abroad or owns assets outside of Canada. Using alternative definitions based on either of these two variables yields almost identical results.

${ }^{37}$ Quantitatively, this impact is similar to that of U.S. tariff reductions. For the average firm $(\log ($ sales $)=6.64$, $\left.\tau_{\text {input }}=4.7 \%\right)$, reducing intermediate input tariffs to zero leads to a predicted abnormal return increase of 3.7 percentage points, compared to an increase of 4.9 percentage points for the elimination of U.S. tariffs.
} 
(8) for dates between 1 November 1987 and 30 June 1988, a period during which the likelihood of CUSFTA's implementation did not vary substantially. I repeatedly draw two consecutive trading dates from this period at random and estimate (8) for these dates. I then calculate cumulative average abnormal returns (CAARs) based on my estimates of $\hat{\gamma}_{1 e}, \hat{\gamma}_{2 e}$ and $\hat{\gamma}_{3 e}$ for these random two-day event windows. I repeat this procedure 1,000 times, thus obtaining a set of 1,000 CAARs estimates comparable to the ones presented in Table 2. I report means, standard deviations and percentiles of the resulting distributions in Table 8.

In the light of the earlier theoretical discussion, one would not expect firm size to matter much as a determinant of abnormal returns in this earlier period, both on its own and when interacted with tariff cuts. On the other hand, if my results so far were picking up some general characteristics of firms or sectors correlated with firm size and tariff cuts, one would expect parameter estimates of the same magnitude as in my baseline results to show up more frequently than expected from pure sampling variation. For example, if large firms in sectors with high future U.S. tariff cuts systematically experienced above average abnormal returns, my baseline and additional results might be due to some (unknown) omitted factor. Table 8 shows that this is not the case for the U.S. tariff cut interaction. The probability of observing two-day U.S.-tariff-related CAARs on randomly chosen dates which are as large or larger than the magnitudes reported in Table 4 is only about $3 \%$. In contrast, the probability of generating two-day Canadian tariff-related CAARs larger than in Table 2 is higher at around $30 \%$. In both cases, however, I am unable to reject the hypothesis that that the mean of my generated CAARs is equal to zero (see column 3 ).

Absolute Price Changes. The model from Section 2 also provides an interesting additional testable prediction related to absolute price changes which I briefly discuss here. Recall that in response to Canadian tariff reductions, domestic Canadian firms were predicted to see a relatively larger fall in profits than exporters relative to initial profits. However, the absolute decline in profits (i.e., $\Delta \pi$ rather than $\Delta \pi / \pi$ ) is smallest for the least productive firms and largest for the most productive ones. So absolute price changes ( $\Delta p$ rather than $\Delta p / p)$ should be more negative for the more productive exporters than for purely domestic firms. ${ }^{38}$ In contrast, the ranking of absolute profit changes of Canadian firms remains unchanged when looking at U.S. tariff reductions. Existing and new exporters see stronger increases than non-exporters, thus implying that the former should see stronger absolute price increases than the latter. ${ }^{39}$

I test this additional prediction by using absolute price changes $\left(p_{t}-p_{t-1}\right)$ rather than returns as the dependent variable. Using absolute price changes has of course the significant disadvantage that the methodological framework of event studies no longer applies. As a con-

\footnotetext{
${ }^{38}$ From $(1), p_{i t}-p_{i t-1}=e_{i}^{-1}\left(E\left(\pi_{i} \mid I_{t}\right)-E\left(\pi_{i} \mid I_{t-1}\right)\right)$. Since $\Delta \pi\left(\phi, \tau_{i j}, \tau_{i j}^{\prime}\right)=\phi^{\sigma-1} f_{i i}\left(\phi_{i i}^{*^{\prime} 1-\sigma}-\phi_{i i}^{* 1-\sigma}\right)$, and $\phi_{i i}^{*^{\prime}}>\phi_{i i}^{*}$, prices should decline by more for more productive and thus larger firms. Note, however, that discount rates $e_{i}$ do not cancel out when looking at absolute price changes, even if they are not changed by the event itself. So to see stronger absolute price declines for larger firms, I need the additional assumption that differences in $e_{i}$ are either unrelated to size or at least not sufficiently higher for larger firms.

${ }^{39}$ This again assumes that there are no systematic and sufficiently large differences in discount rates (see the previous footnote). Also note that, in contrast to relative profit changes, the ranking of new and existing exporters is now unambiguous, with the most productive (and largest) existing exporters experiencing the strongest absolute profit and price increases (compare footnote 8 ).
} 
sequence, it is now unclear which part of price changes are to be classified as 'normal' and 'abnormal'. The inclusion of stock-specific correlations with the market portfolio also no longer has a theoretical basis. Thus, I estimate an adhoc variant of (8) of the form:

$$
p_{i t}-p_{i t-1}=\alpha_{i}^{\prime}+\sum_{e=1}^{E} d_{e t}\left(d_{j}^{\prime}+\beta_{1 e}^{\prime} d_{i x}+\beta_{2 e}^{\prime} d_{i x} d \tau_{C A N, j}+\beta_{3 e}^{\prime} d_{i x} d \tau_{U S, j}\right)+\eta_{i t}^{\prime}
$$

In Table 9, I show results for my log-sales proxy as well as for the preferred binary sales proxy from Section 5.2, which uses the 30th percentile of industry sales as the relevant cutoff. Interestingly, the Canadian tariff interaction does change sign although it is only significant for the binary sales proxy. Also consistent with the model's predictions, the coefficient on the U.S. tariff interaction remains positive and highly significant. Thus, although the theoretical foundations of these additional results are less robust than that of my baseline specification, they provide additional support for the predictions of the class of heterogeneous firm models analyzed here.

Additional Events. I also present results for the three additional events discussed in Section 3. In Table 10, columns 1-2, I focus on the first trading day after the successful conclusion of negotiations on October 3, 1987. Similar to the election outcome itself, this event increased the likelihood of an implementation of CUSFTA. Unlike the election event, however, there are no concerns here that my results could be driven by the perceived consequences of a Conservative election victory for policies other than CUSFTA. As before, I find stronger abnormal returns of larger relative to smaller firms (column 1). Again, the difference is larger in industries with higher U.S. tariff cuts (column 2). The same is also true for Canadian tariff reductions, although the size of the corresponding coefficient is again an order of magnitude smaller.

In columns 3-4, I look at the effect of John Turner's announcement that he had instructed the Liberal majority in the Canadian Senate to block CUSFTA until after a general election. In columns 5-6, I focus on the impact of the publication of the Gallup poll on November 7 which predicted a twelve percentage point lead for the Liberal Party. Both events lowered the likelihood of a ratification of CUSFTA. According to the theoretical predictions, one would thus expect to see an effect opposite to the first two events. This is indeed what I find. Larger firms experienced lower abnormal returns than smaller firms (columns 3 and 5) and the positive coefficient estimates on all the U.S. tariff interactions indicate that this difference was larger in sectors in which CUSFTA foresaw higher tariff cuts (columns 4 and 6). The coefficients for the Canadian tariff cut interaction are also positive and statistically significant.

Interestingly, the magnitude of the coefficient estimates for all three additional events is smaller than that of the estimates relating to my baseline event, the Conservative election victory on November 21-22 (see Table 2). This is consistent with the idea that the latter event represented the most significant change in CUSFTA's implementation probability, given that its ratification by the Canadian parliament was far from assured just before the election but almost certain right after the Conservative victory. 


\subsection{Quantification of Results}

I now analyze the quantitative importance and plausibility of the estimated abnormal return differences more closely. I present two sets of figures. First, predicted abnormal returns are easily computed using a simple transformation of my baseline equation (8):

$$
\widehat{a r}_{i E}=\sum_{e=1}^{E} d_{e t}\left(\hat{d}_{j}+\hat{\gamma}_{1 e} d_{i x}+\hat{\gamma}_{2 e} d_{i x} d \tau_{C A N, j}+\hat{\gamma}_{3 e} d_{i x} d \tau_{U S, j}\right)
$$

where $\widehat{a r}_{i E}$ denotes the predicted value of the (cumulative) abnormal returns of stock $i$ during event window $E$ (here, the election victory of the Conservatives on November 21 and 22).

Secondly, I also compute implied profit changes. I do so by using the link between returns and profits implicit in equation (1), and solving for profit changes as a function of predicted abnormal returns and ex-ante and ex-post implementation probabilities:

$$
\begin{aligned}
1+\widehat{a r}_{i E} & =\frac{E\left(\pi_{i} \mid I_{t+\varepsilon}\right)}{E\left(\pi_{i} \mid I_{t}\right)}=\frac{\operatorname{prob}_{C t+\varepsilon} \pi_{i C}+\left(1-\operatorname{prob}_{C t+\varepsilon}\right) \pi_{i N C}}{\operatorname{prob}_{C t} \pi_{i C}+\left(1-\operatorname{prob}_{C t}\right) \pi_{i N C}} \\
& \Leftrightarrow \frac{\left(\pi_{i C}-\pi_{i N C}\right)}{\pi_{i N C}}=\frac{\widehat{a r}_{i E}}{\operatorname{prob}_{C t+\varepsilon}-\left(1+\widehat{a r}_{i E}\right) p_{r o b} t}
\end{aligned}
$$

where $\widehat{a r}_{i E}$ are the predicted abnormal returns during the election event, $\pi_{i C}$ are per-period profits after a successful implementation of CUSFTA, and $\pi_{i N C}$ per-period profits without CUSFTA. $I_{t}$ denotes information available at time $t$, and $\operatorname{prob}_{C t}$ and $\operatorname{prob}_{C t+\varepsilon}$ the probability of a successful implementation of CUSFTA before and after the Conservative election victory, respectively. Note that I use $E\left(\pi_{i} \mid I_{t}\right)=\operatorname{prob}_{C t} \pi_{i C}+\left(1-\operatorname{prob}_{C t}\right) \pi_{i N C}$ in the above derivation. That is, the expected future profitability of firm $i$ is a weighted mean of profits with and without CUSFTA, where the weights represent the probability of CUSFTA's implementation. It is this probability which changes with the election (i.e., between time $t$ and $t+\varepsilon$ ). Note that I require assumptions about the probability of CUSFTA's implementation prior to and after the Conservative election victory, and not just about the change in the probability.

Intuitively, the size of the predicted abnormal returns is a function of the net present value of profits under the free-trade regime and the alternative scenario without tariff cuts, as well as the change in the likelihood of CUSFTA's implementation brought about by the Conservative election victory (controlling for the ex-ante probability, prob $_{C t}$ ). If discount rates are not changed by the election result, the change in the net present value of profits in turn is equal to the change in per-period profits. Note, however, that linking returns and profits in this way requires (1) to hold exactly, rather than as an approximation as was required previously (compare the discussion in Section 2.1). Any biases arising from the fact that I am using a sample of publicly traded (and thus larger) firms will of course also be more relevant here then for the qualitative findings presented so far. Thus, the results in this section are best seen as back-ofthe-envelope calculations suitable for judging the quantitative importance and plausibility of my estimates, rather than as providing information about the structural parameters or results in standard quantitative trade models.

With these caveats in mind, I turn to an interpretation of my quantitative results. The first 
line of Table 11 reports the averages of predicted abnormal returns for large and small firms, respectively, for the election event window. I first use my preferred binary sales-based proxy for $d_{i x}$ (see Table 3, column 2) to compute abnormal returns, since the 0-1 classification of firms into large and small used there makes the presentation of results straightforward. According to these estimates, large firms experienced predicted abnormal returns of $0.9 \%$ on average, and small firms of $-0.1 \%$, yielding a difference of one percentage point (see column 1 ).

As noted before, these predicted abnormal returns are also likely to be influenced by the general impact of a Conservative election victory on stock markets, and possibly by a differential impact across smaller and larger firms (e.g., if the Conservatives were perceived to be "pro big business"). To strip out these two types of confounding impacts, columns 2 and 3 present average predicted abnormal returns based on (10) but disregard industry fixed effects (column 2 ) or industry fixed effects and the non-interacted export dummy $\left(d_{i x}\right.$, column 3$)$ in the return computation. Focusing on these parts of predicted abnormal returns, which are more closely linked to the predictions of heterogenous firm models, yields a larger return difference between large and small firms of 1.1 percentage points (column 2) and 2.7 percentage points (column 3).

Columns 4-6 compute the same statistics but use estimates based on my baseline proxy of $d_{i x}$, the log of firm sales (see Table 2, column 2). For comparison with the previous binary measure, I classify all firms as large which have sales above the 30th percentile of their respective industry (but I do use actual sales values to compute the predicted abnormal returns of individual firms before taking averages). Results in columns 4-6 are very similar to columns 1-3, with estimated return differences of one percentage points for the full specification with industry fixed effects, 1.1 percentage points for the specification excluding industry fixed, and 3.1 percentage points for the specification excluding both industry fixed effects and the level term in log sales.

In lines 2-5 of Table 11, I present results for implied profit changes, using different sets of assumptions about ex-ante and ex-post implementation probabilities. Given the strong support for CUSFTA voiced by the Conservatives and the fact that their representatives had negotiated the agreement in the first place, it seems appropriate to set the ex-post implementation probability to $100 \%$ in all scenarios. The implied profit change is thus determined by assumptions about the ex-ante likelihood of implementation. In line 2, I use a value of $0 \%$ which is the most conservative assumption in the sense of yielding the smallest implied profit changes. The corresponding results thus provides a useful lower bound for the true profit impact of CUSFTA. Lines 3-5 make more realistic assumptions about the ex-ante probabilities. As discussed, the likelihood of a Conservative election victory was estimated by most observers to be not more than $50 \%$ prior to the publication of the opinion polls on November 19. Thus, in lines 3-5 I choose ex-ante probabilites centered around 50\% (30\%, 50\% and 70\%, respectively).

As can be easily verified from (11), implied profit changes are equal to abnormal returns in the most conservative scenario of a $0 \%-100 \%$ change in the implementation probability of CUSFTA, and increase for higher ex-ante probabilities. Depending on the specific way of calculating predicted abnormal returns and the assumptions about ex-ante probabilities, the average implied difference in profit changes between large and small firms lies between 1 and 10 percentage points for my binary proxy. The corresponding results for my log-sales measure span a slightly wider range, reaching from one percentage point to close to 14 percentage 
points in the least conservative scenario. In my view, these magnitudes are clearly economically significant but not implausibly large given the substantial effects of CUSFTA on the Canadian manufacturing sector found previously by authors such as Trefler (2004).

\section{Conclusions}

This paper presented new empirical evidence on key predictions of heterogeneous firm models. Using the uncertainty surrounding the negotiation and ratification of the Canada-United States Free Trade Agreement in 1987 and 1988, I showed that the pattern of abnormal returns of Canadian manufacturing firms was broadly consistent with the predictions of a class of models based on Melitz (2003).

\section{References}

[1] Amiti, M. and J. Konings (2007), "Trade Liberalization, Intermediate Inputs, and Productivity: Evidence from Indonesia," American Economic Review, 97(5), 1611-1638.

[2] Baldwin, J.R. and W. Gu (2003), "Export-market participation and productivity performance in Canadian manufacturing," Canadian Journal of Economics, 36(3), 634-657.

[3] Bernard, A.B. and J.B. Jensen (1999), "Exceptional Exporter Performance: Cause, Effect, or Both?," Journal of International Economics, 47, 1, 1-25.

[4] Bernard, A.B., J.B. Jensen and P.K. Schott (2006), "Trade Costs, Firms, and Productivity," Journal of Monetary Economics, 53, 917-937.

[5] Bernard, A.B., J.B. Jensen, S. Redding and P. Schott (2007), "Firms in International Trade." Journal of Economic Perspectives, 21(3), 105-130.

[6] Binder, J.J. (1998), "The Event Study Methodology since 1969," Review of Quantitative Finance and Accounting, 11, 111-137.

[7] Bloningen, B., K. Tomlin and W. Wilson (2004), "Tariff-jumping FDI and domestic firms' profits," Canadian Journal of Economics, 37(3), 656-677.

[8] Bloningen, B. (2005), "A Review of the Empirical Literature on FDI Determinants," Atlantic Economic Journal, 33, 383-403.

[9] Brander, J.A. (1991), "Election Polls, Free Trade, and the Stock Market: Evidence from the 1988 Canadian General Election," Canadian Journal of Economics, 24, 827-843.

[10] Brealey, R. and S. Myers (2000), Principles of Corporate Finance, McGraw-Hill.

[11] Breinlich, H. and A. Cuñat (2013), "Tariffs, Trade and Productivity: A Quantitative Evaluation of Heterogeneous Firm Models," CEPR Discussion Paper 9579.

[12] Burstein, A. and M. Melitz (2011), "Trade Liberalization and Firm Dynamics," mimeo, Harvard University.

[13] Burstein, A. and J. Cravino (2014), "Measured Aggregate Gains from International Trade," forthcoming, American Economic Journal - Macroeconomics. 
[14] Bustos, P. (2011), "Trade Liberalization, Exports, and Technology Upgrading: Evidence on the Impact of MERCOSUR on Argentinian Firms," American Economic Review, 101, 304-340.

[15] Campbell J.Y., A.W. Lo and A.C. MacKinlay (1997), The Econometrics of Financial Markets, Princeton University Press.

[16] Chaney, T. (2008), "Distorted Gravity: The Intensive and Extensive Margins of International Trade," American Economic Review, 98(4), September.

[17] Chen, L., Z. Da and X. Zhao (2013), "What Drives Stock Price Movements?" The Review of Financial Studies, 26(4), 841-876.

[18] Cochrane, J.H. (2011), "Discount rates," Journal of Finance, 66, 1047-1108.

[19] De Loecker, J. (2007), "Do exports generate higher productivity? Evidence from Slovenia," Journal of International Economics, 73, 69-98.

[20] Frizzell, A., J. Pammett, and A Westell (1988), "The Canadian General Election of 1988," Carleton University Press, Ottawa, Canada.

[21] Grossman, G.M. and J.A. Levinsohn (1989), "Import Competition and the Stock Market Return to Capital," American Economic Review, 79(5), 1065-1087.

[22] Halpern, L. M. Koren, and A. Szeidl (2011), "Imported Inputs and Productivity," mimeo, Central European University.

[23] Hartigan, J.C., Perry, P.R. and S. Kamma (1986), "The Value of Administered Protection: A Capital Market Approach," Review of Economics and Statistics, 68(4), 610-617.

[24] Hartigan, J.C., S. Kamma, and P.R. Perry (1989), "The injury determination category and the value of relief from dumping," Review of Economics and Statistics, 71, 183-86.

[25] Hughes, J.S., S. Lenway, and J. Rayburn (1997), "Stock price effects of U.S. trade policy responses to Japanese trading practices in semi-conductors," Canadian Journal of Economics, 30, 922-42.

[26] Johnston, R., A. Blais, and H. Brady (1992), "Letting the people decide. Dynamics of a Canadian election," McGill-Queen's University Press, Montréal and Kingston.

[27] Koijen, R., and S. Van Nieuwerburgh (2011), "Predictability of returns and cash flows," Annual Review of Financial Economics, 3, 467-491.

[28] Melitz, M.J. (2003), "The Impact of Trade on Intra-industry Reallocations and Aggregate Industry Productivity," Econometrica, 71, 1695-1725.

[29] Melitz, M.J. and G.I. Ottaviano (2008), "Market Size, Trade, and Productivity," Review of Economic Studies, 75, 295-316.

[30] Morck, R., D. Strangeland, and B. Yeung (1988), "Inherited Wealth, Corporate Control and Economic Growth: The Canadian Disease?" NBER Working Paper 6814.

[31] Statistics Canada (2000), "A Profile of Canadian Exporters," Statistics Canada Publication.

[32] Thompson, A.J. (1993), "The anticipated sectoral adjustment to the Canada - United States Free Trade Agreement: an event study analysis", Canadian Journal of Economics, 26(2), 253-271. 
[33] Topalova, P. and A. Khandelwal (2011), "Trade Liberalization and Firm Productivity: The Case of India", Review of Economics and Statistics, 93(3), 995-1009.

[34] Trefler, D. (2004), "The Long and Short of the Canada-U.S. Free Trade Agreement," American Economic Review, 94(4), 870-895.

[35] Tybout, J. (2001), "Plant- and firm-level evidence on 'New' trade theories," NBER Working Paper 8418. Later published in: Choi, E.K., Harrigan, J. (Eds.), Handbook of International Economics. Basil-Blackwell, Oxford. 
Table 1: Summary Statistics

\begin{tabular}{|c|c|c|c|c|c|c|}
\hline \multirow{2}{*}{ Industry } & \multirow{2}{*}{$\#$} & \multicolumn{3}{|c|}{ Sales } & \multirow{2}{*}{$\mathrm{d} \tau_{\mathrm{CAN}}$} & \multirow{2}{*}{$\mathrm{d} \tau_{\mathrm{US}}$} \\
\hline & & Median & Min & $\operatorname{Max}$ & & \\
\hline Aerospace \& Defense & 10 & 238.7 & 39.5 & 1456.4 & $-2.7 \%$ & $-2.6 \%$ \\
\hline Automobiles \& Parts & 6 & 412.0 & 113.2 & 15943.3 & $-0.4 \%$ & $-0.2 \%$ \\
\hline Beverages & 9 & 57.1 & 4.7 & 4611.0 & $-26.6 \%$ & $-1.8 \%$ \\
\hline Chemicals & 7 & 158.0 & 32.8 & 1385.4 & $-5.2 \%$ & $-4.5 \%$ \\
\hline Construction \& Materials & 21 & 206.5 & 0.7 & 4715.0 & $-6.0 \%$ & $-2.9 \%$ \\
\hline Electronic \& Electrical Equipment & 14 & 72.3 & 0.1 & 1797.7 & $-3.3 \%$ & $-2.7 \%$ \\
\hline Food Producers & 19 & 354.5 & 3.2 & 3804.0 & $-4.3 \%$ & $-2.2 \%$ \\
\hline Forestry \& Paper & 22 & 526.1 & 43.1 & 5819.1 & $-3.3 \%$ & $-0.6 \%$ \\
\hline General Industrials & 8 & 467.5 & 1.5 & 6499.8 & $-7.5 \%$ & $-2.8 \%$ \\
\hline Healthcare Equipment \& Services & 4 & 33.0 & 0.3 & 205.9 & $-4.3 \%$ & $-2.8 \%$ \\
\hline Household Goods & 12 & 101.8 & 10.4 & 450.5 & $-8.2 \%$ & $-3.0 \%$ \\
\hline Industrial Engineering & 18 & 97.2 & 2.7 & 1737.5 & $-0.8 \%$ & $-0.4 \%$ \\
\hline Industrial Metals & 24 & 408.6 & 0.1 & 10175.0 & $-2.8 \%$ & $-2.0 \%$ \\
\hline Leisure Goods & 6 & 308.9 & 93.7 & 1110.5 & $-4.6 \%$ & $-3.0 \%$ \\
\hline Media & 27 & 159.2 & 0.2 & 4467.9 & $0.0 \%$ & $0.0 \%$ \\
\hline Oil Equipment \& Services & 20 & 14.5 & 0.7 & 3941.0 & $-2.3 \%$ & $-1.5 \%$ \\
\hline Personal Goods & 3 & 157.1 & 8.7 & 1217.2 & $-12.7 \%$ & $-8.7 \%$ \\
\hline Pharmaceuticals \& Biotechnology & 6 & 0.9 & 0.1 & 156.3 & $-4.7 \%$ & $-2.3 \%$ \\
\hline Technology Hardware \& Equipment & 9 & 28.5 & 2.7 & 6451.3 & $-1.6 \%$ & $-1.9 \%$ \\
\hline Tobacco & 2 & 2629.2 & 413.9 & 4844.5 & $-1.4 \%$ & $0.0 \%$ \\
\hline Total & 247 & 178.3 & 0.1 & 15943.3 & $-5.1 \%$ & $-2.3 \%$ \\
\hline
\end{tabular}

Notes: Table shows descriptive statistics on the number of firms per industry, firm-level sales (in mill. $\$ C N D$ ), and average tariff cuts implemented under CUSFTA. See text for details. 
Figure 1: Cumulative average returns during the Canadian election campaign of 1988

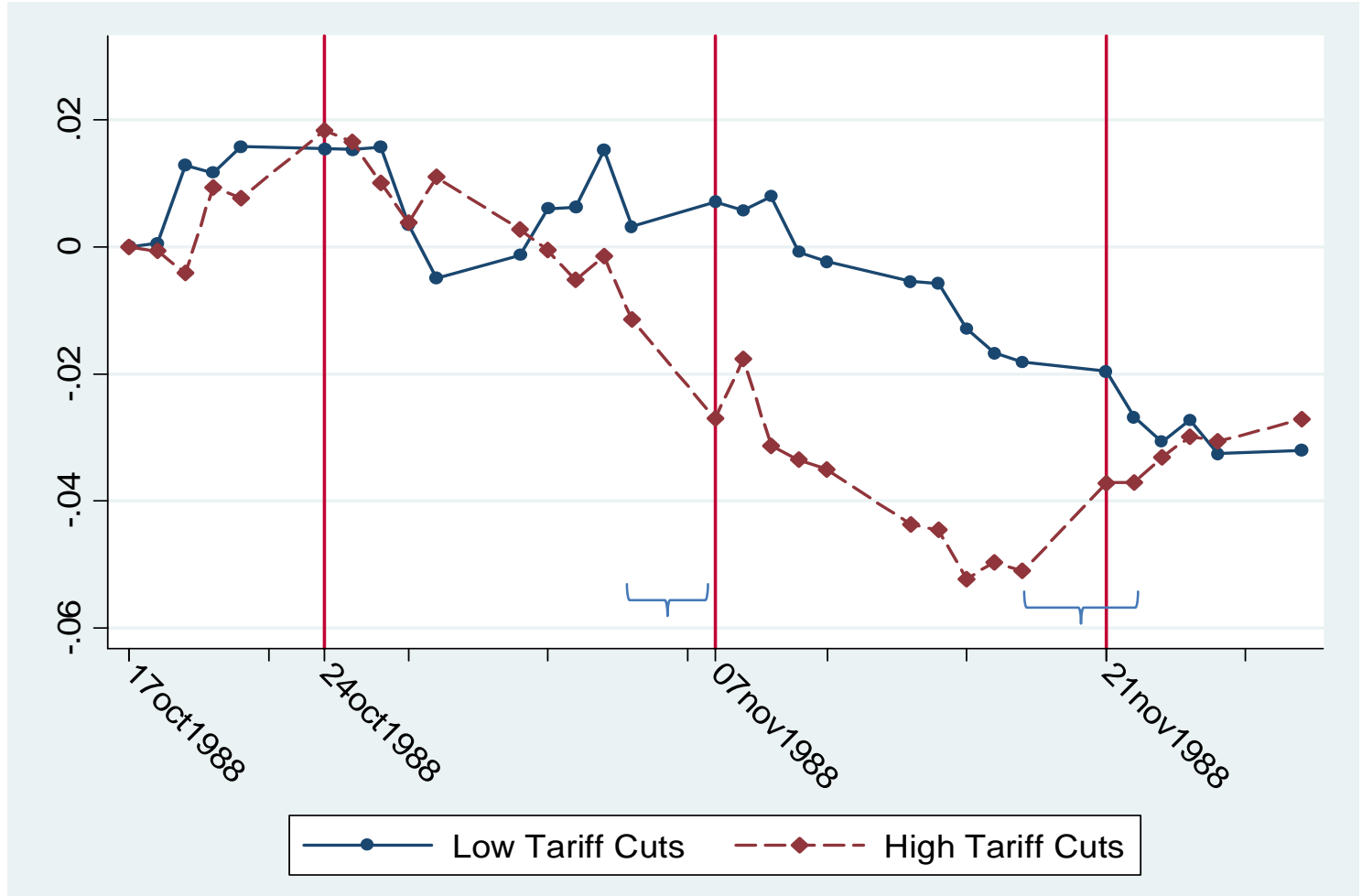

Notes: Figure shows differences in cumulative average returns (CARs) between firms above and below the $50^{\text {th }}$ sales percentile in each industry for two groups of industries: the $50 \%$ of industries with the largest U.S. tariff cuts and the $50 \%$ of industries with the smallest U.S. tariff cuts. All CARs are normalized to zero on October 17 and calculated at the end of each day (so that the difference between $\mathrm{CAR}_{\mathrm{t}}$ and $\mathrm{CAR}_{\mathrm{t}-1}$ measures the market reaction on day $\mathrm{t}$ ). See text for details.

\section{Table 2: Baseline Results}

\begin{tabular}{lcc}
\hline & $(1)$ & $(2)$ \\
& Return & Return \\
\hline $\mathrm{d}_{\mathrm{e}}{ }^{*} \mathrm{~d}_{\mathrm{x}}$ & 0.003 & -0.006 \\
$\mathrm{~d}_{\mathrm{e}} * \mathrm{~d}_{\mathrm{x}} * \mathrm{~d} \tau_{\mathrm{US}}$ & $(9.936)^{* *}$ & $(12.661)^{* *}$ \\
$\mathrm{~d}_{\mathrm{e}} * \mathrm{~d}_{\mathrm{x}} * \mathrm{~d} \tau_{\mathrm{CAN}}$ & & -0.420 \\
& & $(18.832)^{* *}$ \\
Firms & & -0.015 \\
Event Window & 247 & $(3.745)^{* *}$ \\
Length Event Window & Nov. 21-22 & 247 \\
Observations Event Window & 2 days & Nov. $21-22$ \\
\hline
\end{tabular}

Notes: Table shows cumulative average abnormal returns from market-model OLS regressions (figures in brackets are t-stats based on standard errors clustered per trading day). The dependent variable is daily stock returns. See text for specification details (equations 7 and 8). The independent variables shown in the table are event dummies $\left(d_{e}\right)$ interacted with the log of sales (the proxy for $d_{x}$ ), and triple interactions between the event dummy, log sales and Canadian tariff cuts $\left(\mathrm{d} \tau_{\mathrm{CAN}}\right)$ or U.S. tariff cuts $\left(\mathrm{d} \tau_{\mathrm{US}}\right)$, respectively. All specifications include industry fixed effects interacted with the event dummies.,$+{ }^{*}$, and $* *$ denote statistical significance at the $10 \%, 5 \%$ and $1 \%$ level, respectively. 
Table 3: Alternative Measures of Firm Heterogeneity I: Sales-Based Measures

\begin{tabular}{|c|c|c|c|c|c|c|c|c|c|c|c|c|}
\hline & $\begin{array}{c}(1) \\
\text { Return }\end{array}$ & $\begin{array}{c}(2) \\
\text { Return }\end{array}$ & $\begin{array}{c}(3) \\
\text { Return }\end{array}$ & $\begin{array}{c}(4) \\
\text { Return }\end{array}$ & $\begin{array}{c}(5) \\
\text { Return }\end{array}$ & $\begin{array}{c}(6) \\
\text { Return }\end{array}$ & $\begin{array}{c}(7) \\
\text { Return }\end{array}$ & $\begin{array}{c}(8) \\
\text { Return }\end{array}$ & $\begin{array}{c}(9) \\
\text { Return }\end{array}$ & $\begin{array}{c}(10) \\
\text { Return }\end{array}$ & $\begin{array}{c}(11) \\
\text { Return }\end{array}$ & $\begin{array}{c}(12) \\
\text { Return }\end{array}$ \\
\hline $\mathrm{d}_{\mathrm{e}}^{*} \mathrm{~d}_{\mathrm{x}}$ & $\begin{array}{c}0.009 \\
(7.923)^{* *}\end{array}$ & $\begin{array}{c}-0.015 \\
(8.461)^{* *}\end{array}$ & $\begin{array}{c}0.019 \\
(12.325)^{* *}\end{array}$ & $\begin{array}{c}-0.009 \\
(3.548)^{* *}\end{array}$ & $\begin{array}{c}0.007 \\
(6.661)^{* *}\end{array}$ & $\begin{array}{c}-0.024 \\
(12.428)^{* *}\end{array}$ & $\begin{array}{c}0.008 \\
(8.815)^{* *}\end{array}$ & $\begin{array}{c}-0.020 \\
(14.059)^{* *}\end{array}$ & $\begin{array}{c}0.004 \\
(4.996)^{* *}\end{array}$ & $\begin{array}{c}-0.013 \\
(12.861)^{* *}\end{array}$ & $\begin{array}{c}0.014 \\
(11.799)^{* *}\end{array}$ & $\begin{array}{c}-0.012 \\
(7.512)^{* *}\end{array}$ \\
\hline $\mathrm{d}_{\mathrm{e}} * \mathrm{~d}_{\mathrm{x}} * \mathrm{~d} \tau_{\mathrm{US}}$ & & $\begin{array}{c}-0.928 \\
(7.991)^{* *}\end{array}$ & & $\begin{array}{c}-1.792 \\
(11.689)^{* *}\end{array}$ & & $\begin{array}{c}-1.311 \\
(13.568)^{* *}\end{array}$ & & $\begin{array}{c}-1.351 \\
(17.165)^{* *}\end{array}$ & & $\begin{array}{c}-0.755 \\
(13.939)^{* *}\end{array}$ & & $\begin{array}{c}-1.140 \\
(14.625)^{* *}\end{array}$ \\
\hline $\mathrm{d}_{\mathrm{e}} * \mathrm{~d}_{\mathrm{x}} * \mathrm{~d} \tau_{\mathrm{CAN}}$ & & $\begin{array}{c}-0.208 \\
(6.784)^{* *} \\
\end{array}$ & & $\begin{array}{c}0.084 \\
(1.915)+ \\
\end{array}$ & & $\begin{array}{c}-0.166 \\
(6.797)^{* *}\end{array}$ & & $\begin{array}{c}-0.061 \\
(2.639)^{* *} \\
\end{array}$ & & $\begin{array}{c}-0.065 \\
(3.869)^{* *} \\
\end{array}$ & & $\begin{array}{c}-0.097 \\
(3.855)^{* *} \\
\end{array}$ \\
\hline Size cutoff & $\begin{array}{c}>30 \text { th } \\
\text { percent. }\end{array}$ & $\begin{array}{c}>30 \text { th } \\
\text { percent. }\end{array}$ & $\begin{array}{l}>20 \text { th } \\
\text { percent. }\end{array}$ & $\begin{array}{l}>20 \text { th } \\
\text { percent. }\end{array}$ & $\begin{array}{c}>40 \text { th } \\
\text { percent. }\end{array}$ & $\begin{array}{c}>40 \text { th } \\
\text { percent. }\end{array}$ & $\begin{array}{l}>60 \text { th } \\
\text { percent. }\end{array}$ & $\begin{array}{c}>60 \text { th } \\
\text { percent. }\end{array}$ & $\begin{array}{l}>80 \text { th } \\
\text { percent. }\end{array}$ & $\begin{array}{c}>80 \text { th } \\
\text { percent. }\end{array}$ & $\begin{array}{c}\text { Sectoral } \\
\text { variation }\end{array}$ & $\begin{array}{c}\text { Sectoral } \\
\text { variation }\end{array}$ \\
\hline Firms & 247 & 247 & 247 & 247 & 247 & 247 & 247 & 247 & 247 & 247 & 247 & 247 \\
\hline Event Window & $\begin{array}{l}\text { Nov. } \\
21-22\end{array}$ & $\begin{array}{l}\text { Nov. } \\
21-22\end{array}$ & $\begin{array}{l}\text { Nov. } \\
21-22\end{array}$ & $\begin{array}{l}\text { Nov. } \\
21-22\end{array}$ & $\begin{array}{l}\text { Nov. } \\
21-22\end{array}$ & $\begin{array}{l}\text { Nov. } \\
21-22\end{array}$ & $\begin{array}{l}\text { Nov. } \\
21-22\end{array}$ & $\begin{array}{l}\text { Nov. } \\
21-22\end{array}$ & $\begin{array}{l}\text { Nov. } \\
21-22\end{array}$ & $\begin{array}{l}\text { Nov. } \\
21-22\end{array}$ & $\begin{array}{l}\text { Nov. } \\
21-22\end{array}$ & $\begin{array}{l}\text { Nov. } \\
21-22\end{array}$ \\
\hline $\begin{array}{l}\text { Event Window } \\
\text { Length }\end{array}$ & 2 days & 2 days & 2 days & 2 days & 2 days & 2 days & 2 days & 2 days & 2 days & 2 days & 2 days & 2 days \\
\hline $\begin{array}{l}\text { Observations } \\
\text { Event Window }\end{array}$ & 494 & 494 & 494 & 494 & 494 & 494 & 494 & 494 & 494 & 494 & 494 & 494 \\
\hline
\end{tabular}

Notes: Table shows cumulative average abnormal returns from market-model OLS regressions (figures in brackets are t-stats based on standard errors clustered per trading day). See Table 2 and text for details (equations 7 and 8 and Section 5.2 ). +, *, and ** denote statistical significance at the $10 \%, 5 \%$ and $1 \%$ level. 
Table 4: Alternative Measures of Firm Heterogeneity II: Export Status.

\begin{tabular}{|c|c|c|c|c|c|c|c|c|c|c|}
\hline & (1) Return & (2) Return & (3) Return & (4) Return & (5) Return & (6) Return & (7) Return & (8) Return & (9) Return & (10) Return \\
\hline \multirow[t]{2}{*}{$\mathrm{d}_{\mathrm{e}}^{*} \mathrm{~d}_{\mathrm{x}}$} & 0.016 & 0.013 & 0.015 & 0.012 & 0.014 & 0.010 & 0.015 & 0.013 & 0.002 & 0.002 \\
\hline & $(14.266)^{* *}$ & $(12.098)^{* *}$ & $(14.726)^{* *}$ & $(10.993)^{* *}$ & $(16.220)^{* *}$ & $(11.151)^{* *}$ & $(15.854)^{* *}$ & $(11.511)^{* *}$ & $(14.798)^{* *}$ & $(10.639)^{* *}$ \\
\hline \multirow[t]{2}{*}{$\mathrm{d}_{\mathrm{e}} * \mathrm{~d}_{\mathrm{x}} * \mathrm{~d} \tau_{\mathrm{US}}$} & & -0.338 & & -0.380 & & -0.386 & & -0.299 & & -0.051 \\
\hline & & $(8.122)^{* *}$ & & $(9.551)^{* *}$ & & $(10.615)^{* *}$ & & $(8.430)^{* *}$ & & $(10.062)^{* *}$ \\
\hline \multirow{2}{*}{$\mathrm{d}_{\mathrm{e}} * \mathrm{~d}_{\mathrm{x}} * \mathrm{~d} \tau_{\mathrm{CAN}}$} & & 0.061 & & 0.064 & & 0.057 & & 0.061 & & 0.009 \\
\hline & & $(3.056)^{* *}$ & & $(4.989)^{* *}$ & & $(7.814)^{* *}$ & & $(8.137)^{* *}$ & & $(9.785)^{* *}$ \\
\hline Definition of $\mathrm{d}_{\mathrm{x}}$ & $\begin{array}{c}\text { Exporter in } \\
1988\end{array}$ & $\begin{array}{c}\text { Exporter in } \\
1988\end{array}$ & $\begin{array}{c}\text { Exporter in } \\
1988-1997\end{array}$ & $\begin{array}{c}\text { Exporter in } \\
1988-1997\end{array}$ & $\begin{array}{c}\text { Sales }>30 \text { th } \\
\text { percent. }\end{array}$ & $\begin{array}{c}\text { Sales }>30 \text { th } \\
\text { percent. }\end{array}$ & $\begin{array}{c}\text { Sales }>20 \text { th } \\
\text { percent. }\end{array}$ & $\begin{array}{l}\text { Sales }>20 \text { th } \\
\text { percent. }\end{array}$ & $\log$ (sales) & $\log$ (sales) \\
\hline Firms & 54 & 54 & 54 & 54 & 54 & 54 & 54 & 54 & 54 & 54 \\
\hline Event Window & Nov. 21-22 & Nov. 21-22 & Nov. 21-22 & Nov. $21-22$ & Nov. 21-22 & Nov. $21-22$ & Nov. 21-22 & Nov. $21-22$ & Nov. 21-22 & Nov. 21-22 \\
\hline Event Window Length & 2 days & 2 days & 2 days & 2 days & 2 days & 2 days & 2 days & 2 days & 2 days & 2 days \\
\hline Observations Event Window & 108 & 108 & 108 & 108 & 108 & 108 & 108 & 108 & 108 & 108 \\
\hline
\end{tabular}

Notes: Table shows cumulative average abnormal returns from market-model OLS regressions (figures in brackets are t-stats based on standard errors clustered per trading day). See Table 2 and text for details (equations 7 and 8 and Section 5.2 ). $+{ }^{*}$, and $* *$ denote statistical significance at the $10 \%, 5 \%$ and $1 \%$ level.

Table 5: Alternative Measures of Firm Heterogeneity III: Employment and Labor Productivity.

\begin{tabular}{|c|c|c|c|c|c|c|c|c|}
\hline & (1) Return & (2) Return & (3) Return & (4) Return & (5) Return & (6) Return & (7) Return & (8) Return \\
\hline $\mathrm{d}_{\mathrm{e}} * \mathrm{~d}_{\mathrm{x}}$ & $\begin{array}{c}0.002 \\
(7.307)^{* *}\end{array}$ & $\begin{array}{c}-0.008 \\
(16.264)^{* *}\end{array}$ & $\begin{array}{c}0.006 \\
(4.191)^{* *}\end{array}$ & $\begin{array}{c}-0.019 \\
(10.307)^{* *}\end{array}$ & $\begin{array}{c}0.004 \\
(7.285)^{* *}\end{array}$ & $\begin{array}{c}-0.010 \\
(8.644)^{* *}\end{array}$ & $\begin{array}{c}0.007 \\
(5.136)^{* *}\end{array}$ & $\begin{array}{l}-0.015 \\
(5.321)^{* *}\end{array}$ \\
\hline $\mathrm{d}_{\mathrm{e}} * \mathrm{~d}_{\mathrm{x}} * \mathrm{~d} \tau_{\mathrm{US}}$ & & $\begin{array}{c}-0.461 \\
(16.724)^{* *}\end{array}$ & & $\begin{array}{c}-0.917 \\
(6.511)^{* *}\end{array}$ & & $\begin{array}{c}-0.685 \\
(11.130)^{* *}\end{array}$ & & $\begin{array}{c}-1.475 \\
(9.364)^{* *}\end{array}$ \\
\hline $\mathrm{d}_{\mathrm{e}} * \mathrm{~d}_{\mathrm{x}} * \mathrm{~d} \tau_{\mathrm{CAN}}$ & & $\begin{array}{c}-0.024 \\
(5.099)^{* *}\end{array}$ & & $\begin{array}{c}-0.257 \\
(7.545)^{* *}\end{array}$ & & $\begin{array}{l}-0.009 \\
(0.675)\end{array}$ & & $\begin{array}{c}0.056 \\
(1.030)\end{array}$ \\
\hline Definition of $d_{x}$ & $\log ($ empl. $)$ & $\log ($ empl. $)$ & $\begin{array}{c}\text { empl. }>30 \text { th } \\
\text { percentile }\end{array}$ & $\begin{array}{l}\text { empl. }>30 \text { th } \\
\text { percentile }\end{array}$ & $\log$ (lab.prod.) & $\log$ (lab.prod.) & $\begin{array}{c}\text { lab.prod. }>30 \text { th } \\
\text { percentile }\end{array}$ & $\begin{array}{l}\text { lab.prod. }>30 \text { th } \\
\text { percentile }\end{array}$ \\
\hline Firms & 210 & 210 & 210 & 210 & 210 & 210 & 210 & 210 \\
\hline Event Window & Nov. 21-22 & Nov. 21-22 & Nov. 21-22 & Nov. $21-22$ & Nov. 21-22 & Nov. 21-22 & Nov. $21-22$ & Nov. 21-22 \\
\hline Event Window Length & 2 days & 2 days & 2 days & 2 days & 2 days & 2 days & 2 days & 2 days \\
\hline Observations Event Window & 420 & 420 & 420 & 420 & 420 & 420 & 420 & 420 \\
\hline
\end{tabular}

Notes: Table shows cumulative average abnormal returns from market-model OLS regressions (figures in brackets are t-stats based on standard errors clustered per trading day). See Table 2 and the text for details (equations 7 and 8 and Section 5.2 ). +, *, and ** denote statistical significance at the $10 \%, 5 \%$ and $1 \%$. 
Table 6: Changes in Market-Model Parameters and Discount Rates

\begin{tabular}{|c|c|c|c|c|}
\hline & $\begin{array}{c}(1) \\
\text { Return }\end{array}$ & $\begin{array}{c}(2) \\
\text { Return }\end{array}$ & $\begin{array}{c}(3) \\
\text { Return }\end{array}$ & $\begin{array}{c}(4) \\
\text { Return }\end{array}$ \\
\hline $\mathrm{d}_{\mathrm{e}}^{*} \mathrm{~d}_{\mathrm{x}}$ & $\begin{array}{c}-0.006 \\
(13.388)^{* *}\end{array}$ & $\begin{array}{c}-0.004 \\
(3.120)^{* *}\end{array}$ & $\begin{array}{c}-0.006 \\
(12.186)^{* *}\end{array}$ & $\begin{array}{c}-0.006 \\
(12.662)^{* *}\end{array}$ \\
\hline $\mathrm{d}_{\mathrm{e}} * \mathrm{~d}_{\mathrm{x}} * \mathrm{~d} \tau_{\mathrm{US}}$ & $\begin{array}{c}-0.423 \\
(19.604)^{* *}\end{array}$ & $\begin{array}{c}-0.377 \\
(8.891)^{* *}\end{array}$ & $\begin{array}{c}-0.448 \\
(18.359)^{* *}\end{array}$ & $\begin{array}{c}-0.419 \\
(18.796)^{* *}\end{array}$ \\
\hline $\mathrm{d}_{\mathrm{e}} * \mathrm{~d}_{\mathrm{x}} * \mathrm{~d} \tau_{\mathrm{CAN}}$ & $\begin{array}{c}-0.015 \\
(3.727)^{* *}\end{array}$ & $\begin{array}{l}-0.014 \\
(1.625)\end{array}$ & $\begin{array}{c}-0.014 \\
(3.441)^{* *}\end{array}$ & $\begin{array}{c}-0.015 \\
(3.738)^{* *}\end{array}$ \\
\hline $\begin{array}{l}\text { Abnormal Returns Model/ } \\
\text { Estimation Procedure }\end{array}$ & $\begin{array}{c}\text { Market Model, } \\
\text { event-induced } \\
\text { change in } \beta_{\mathrm{i}}\end{array}$ & $\begin{array}{c}\text { Market Model, } \\
\text { event-induced } \\
\text { change in } \alpha_{\mathrm{i}} \text { and } \\
\beta_{\mathrm{i}}\end{array}$ & $\begin{array}{c}\text { Market Model, } \\
\text { drop stocks } \\
\text { with event- } \\
\text { induced change } \\
\text { in } \mathrm{e}_{\mathrm{it}}\end{array}$ & $\begin{array}{l}\text { Market Model, } \\
\text { control for } \\
\text { change in } \mathrm{e}_{\mathrm{it}}\end{array}$ \\
\hline Firms & 247 & 247 & 210 & 247 \\
\hline Event Window & Nov. 21-22 & Nov. $21-22$ & Nov. $21-22$ & Nov. $21-22$ \\
\hline Length Event Window & 2 days & 2 days & 2 days & 2 days \\
\hline Observations Event Window & 494 & 494 & 420 & 494 \\
\hline
\end{tabular}

Notes: Table shows cumulative average abnormal returns from market-model OLS regressions (figures in brackets are t-stats based on standard errors clustered per trading day). See Table 2 and text for details (equations 7 and 8 and Section 5.2).,$+{ }^{*}$, and ${ }^{* *}$ denote statistical significance at the $10 \%, 5 \%$ and $1 \%$ level.

Table 7: Input Tariffs and MNE Status as Controls

\begin{tabular}{|c|c|c|c|}
\hline & $\begin{array}{c}(1) \\
\text { Return }\end{array}$ & $\begin{array}{c}(2) \\
\text { Return }\end{array}$ & $\begin{array}{c}(3) \\
\text { Return }\end{array}$ \\
\hline $\mathrm{d}_{\mathrm{e}}^{*} \mathrm{~d}_{\mathrm{x}}$ & $\begin{array}{c}-0.011 \\
(12.645)^{* *}\end{array}$ & $\begin{array}{c}-0.009 \\
(13.394)^{* *}\end{array}$ & $\begin{array}{c}-0.016 \\
(8.249)^{* *}\end{array}$ \\
\hline $\mathrm{d}_{\mathrm{e}} * \mathrm{~d}_{\mathrm{x}} * \mathrm{~d} \tau_{\mathrm{US}}$ & $\begin{array}{c}-0.395 \\
(17.511)^{* *}\end{array}$ & $\begin{array}{c}-0.555 \\
(15.780)^{* *}\end{array}$ & $\begin{array}{c}-0.480 \\
(10.915)^{* *}\end{array}$ \\
\hline $\mathrm{d}_{\mathrm{e}} * \mathrm{~d}_{\mathrm{x}} * \mathrm{~d} \tau_{\mathrm{CAN}}$ & $\begin{array}{c}-0.011 \\
(2.581)^{*}\end{array}$ & $\begin{array}{c}0.003 \\
(0.487)\end{array}$ & $\begin{array}{c}0.011 \\
(2.148)^{*}\end{array}$ \\
\hline $\mathrm{d}_{\mathrm{e}} * \mathrm{~d}_{\mathrm{x}} * \mathrm{~d} \tau_{\text {INPUT }}$ & $\begin{array}{c}-0.118 \\
(6.162)^{* *}\end{array}$ & & $\begin{array}{c}-0.192 \\
(3.819)^{* *}\end{array}$ \\
\hline $\mathrm{d}_{\mathrm{e}} * \mathrm{~d}_{\mathrm{MNE}}$ & & $\begin{array}{c}0.018 \\
(10.840)^{* *}\end{array}$ & $\begin{array}{c}0.017 \\
(10.509)^{* *}\end{array}$ \\
\hline $\mathrm{d}_{\mathrm{e}} * \mathrm{~d}_{\mathrm{MNE}} * \mathrm{~d} \tau_{\mathrm{US}}$ & & $\begin{array}{c}0.681 \\
(6.760)^{* *}\end{array}$ & $\begin{array}{c}0.649 \\
(6.252)^{* *}\end{array}$ \\
\hline $\mathrm{d}_{\mathrm{e}} * \mathrm{~d}_{\mathrm{MNE}} * \mathrm{~d} \tau_{\mathrm{CAN}}$ & & $\begin{array}{c}0.045 \\
(0.987)\end{array}$ & $\begin{array}{c}0.042 \\
(0.928)\end{array}$ \\
\hline Firms & 247 & 194 & 194 \\
\hline Event Window & Nov. 21-22 & Nov. 21-22 & Nov. $21-22$ \\
\hline Length Event Window & 2 days & 2 days & 2 days \\
\hline Observations Event Window & 494 & 388 & 388 \\
\hline
\end{tabular}

Notes: Table shows cumulative average abnormal returns from market-model OLS regressions (figures in brackets are t-stats based on standard errors clustered per trading day). See Table 2 and text for details (equations 7 and 8 and Section 5.2).,$+{ }^{*}$, and ${ }^{* *}$ denote statistical significance at the $10 \%, 5 \%$ and $1 \%$ level. 
Table 8: Parameter Estimates for Non-Event Dates

\begin{tabular}{|c|c|c|c|c|c|c|c|c|c|}
\hline \multirow{2}{*}{ Coefficient estimate } & \multirow{2}{*}{$\begin{array}{l}\text { Mean } \\
(\mathrm{sd})\end{array}$} & \multirow{2}{*}{$\begin{array}{c}\text { Test mean } \neq 0 \\
(\mathrm{t} \text {-stat })\end{array}$} & \multicolumn{7}{|c|}{ Percentiles } \\
\hline & & & $1 \mathrm{st}$ & 5 th & 10th & 50 th & 90th & 95 th & 99th \\
\hline$\beta_{1 \mathrm{e}}, \log$ sales proxy & $\begin{array}{c}0.000 \\
(0.003)\end{array}$ & 0.81 & -0.009 & -0.006 & -0.004 & 0.000 & 0.004 & 0.005 & 0.006 \\
\hline $\begin{array}{l}\beta_{2 \mathrm{e}}, \text { Canadian tariff-log } \\
\text { sales interaction }\end{array}$ & $\begin{array}{l}-0.001 \\
(0.032)\end{array}$ & 0.97 & -0.079 & -0.059 & -0.045 & 0.000 & 0.039 & 0.048 & 0.069 \\
\hline $\begin{array}{l}\beta_{3 \mathrm{e}}, \text { U.S. tariff-log sales } \\
\text { interaction }\end{array}$ & $\begin{array}{l}-0.005 \\
(0.184)\end{array}$ & 0.80 & -0.468 & -0.312 & -0.243 & -0.012 & 0.230 & 0.291 & 0.466 \\
\hline Number of draws & \multicolumn{9}{|c|}{1,000} \\
\hline Number of firms & \multicolumn{9}{|c|}{247} \\
\hline Length Event Window & \multicolumn{9}{|c|}{2 days } \\
\hline Obs. Event Window & \multicolumn{9}{|c|}{494} \\
\hline
\end{tabular}

Notes: Table shows means, standard deviation and percentiles for the distributions of coefficient estimates shown in the left column. Also shown is the t-stat of a regression of the coefficient estimates on a constant (column "Test mean $\neq 0$ "). See text and Table 2 for further details.

Table 9: Absolute Price Changes

\begin{tabular}{lcc}
\hline & $(1)$ & $(2)$ \\
& $\mathrm{p}_{\mathrm{t}}-\mathrm{p}_{\mathrm{t}-1}$ & $\mathrm{p}_{\mathrm{t}}-\mathrm{p}_{\mathrm{t}-1}$ \\
\hline $\mathrm{d}_{\mathrm{e}}{ }^{*} \mathrm{~d}_{\mathrm{x}}$ & -0.012 & -0.065 \\
& $(1.437)$ & $(1.394)$ \\
$\mathrm{d}_{\mathrm{e}}{ }^{*} \mathrm{~d}_{\mathrm{x}} * \mathrm{~d} \tau_{\mathrm{US}}$ & -1.392 & -16.549 \\
& $(3.480)^{* *}$ & $(5.481)^{* *}$ \\
$\mathrm{~d}_{\mathrm{e}}{ }^{*} \mathrm{~d}_{\mathrm{x}} * \mathrm{~d} \tau_{\mathrm{CAN}}$ & 0.252 & 2.909 \\
& $(1.456)$ & $(2.227)^{*}$ \\
\hline Export Status Definition & $\log (\mathrm{sales})$ & binary $\left(\right.$ sales $>30^{\text {th }}$ percentile) \\
Firms & 247 & 247 \\
Event Window & Nov. $21-22$ & Nov. $21-22$ \\
Length Event Window & 2 days & 2 days \\
Observations Event Window & 494 & 494 \\
\hline
\end{tabular}

Notes: Table shows cumulative average abnormal price changes from OLS regressions (figures in brackets are t-stats based on standard errors clustered per trading day). See text for details (equation 9 and Section 5.2).,$+{ }^{*}$, and ${ }^{* *}$ denote statistical significance at the $10 \%, 5 \%$ and $1 \%$ level. 
Table 10: Additional Events

\begin{tabular}{lcccccc}
\hline & $(1)$ & $(2)$ & $(3)$ & $(4)$ & $(5)$ & $(6)$ \\
& Return & Return & Return & Return & Return & Return \\
\hline $\mathrm{d}_{\mathrm{e}}{ }^{*} \mathrm{~d}_{\mathrm{x}}$ & 0.001 & -0.000 & -0.001 & 0.000 & -0.003 & -0.000 \\
& $(9.139)^{* *}$ & $(2.197)^{*}$ & $(8.710)^{* *}$ & $(1.883)+$ & $(11.317)^{* *}$ & $(0.085)$ \\
$\mathrm{d}_{\mathrm{e}}{ }^{*} \mathrm{~d}_{\mathrm{x}}{ }^{*} \mathrm{~d} \tau_{\text {US }}$ & & -0.062 & & 0.058 & & 0.099 \\
& & $(7.491)^{* *}$ & & $(5.997)^{* *}$ & & $(6.405)^{* *}$ \\
$\mathrm{~d}_{\mathrm{e}}{ }^{*} \mathrm{~d}_{\mathrm{x}}{ }^{*} \mathrm{~d} \tau_{\text {CAN }}$ & & -0.005 & & 0.005 & & 0.028 \\
& & $(3.525)^{* *}$ & & $(2.374)^{*}$ & & $(8.703)^{* *}$ \\
\hline Firms & 247 & 247 & 247 & 247 & 247 & 247 \\
Event Window & Oct.5, 1987 & Oct.5, 1987 & July 20, & July 20, & Nov. 7, & Nov. 7 \\
Length Event Window & 1 day & 1 day & 1 day & 1988 & 1988 & 1988 \\
Obs. Event Window & 247 & 247 & 247 & 247 & 1 day & 1 day \\
\hline
\end{tabular}

Notes: Table shows cumulative average abnormal returns from market-model OLS regressions (figures in brackets are t-stats based on standard errors clustered per trading day). See Table 2 and text for details (equations 7 and 8 and Section 5.2). $+{ }^{*}$, and ${ }^{* *}$ denote statistical significance at the $10 \%, 5 \%$ and $1 \%$ level.

Table 11: Quantification

$(1)$

$(2)$

(3)

$(4)$

$(5)$

$(6)$

Predicted Abnormal Returns

\begin{tabular}{|c|c|c|c|c|c|c|c|}
\hline - & $\begin{array}{l}\text { Small Firms } \\
\text { Large Firms }\end{array}$ & $\begin{array}{l}-0.1 \% \\
0.9 \%\end{array}$ & $\begin{array}{l}0.0 \% \\
1.1 \%\end{array}$ & $\begin{array}{l}0.0 \% \\
2.7 \%\end{array}$ & $\begin{array}{c}-0.1 \% \\
0.9 \%\end{array}$ & $\begin{array}{l}0.3 \% \\
1.4 \%\end{array}$ & $\begin{array}{l}1.6 \% \\
4.7 \%\end{array}$ \\
\hline \multicolumn{8}{|c|}{ Implied Profits Changes $(0-100 \%)$} \\
\hline- & Small Firms & $-0.1 \%$ & $0.0 \%$ & $0.0 \%$ & $-0.1 \%$ & $0.3 \%$ & $1.6 \%$ \\
\hline- & Large Firms & $0.9 \%$ & $1.1 \%$ & $2.7 \%$ & $0.9 \%$ & $1.4 \%$ & $4.7 \%$ \\
\hline \multicolumn{8}{|c|}{ Implied Profits Changes (30-100\%) } \\
\hline - & Small Firms & $-0.0 \%$ & $0.0 \%$ & $0.0 \%$ & $-0.0 \%$ & $0.4 \%$ & $2.4 \%$ \\
\hline - & Large Firms & $1.3 \%$ & $1.6 \%$ & $3.9 \%$ & $1.3 \%$ & $2.1 \%$ & $6.9 \%$ \\
\hline \multicolumn{8}{|c|}{ Implied Profits Changes (50-100\%) } \\
\hline - & Small Firms & $0.0 \%$ & $0.0 \%$ & $0.0 \%$ & $0.0 \%$ & $0.7 \%$ & $3.5 \%$ \\
\hline- & Large Firms & $1.8 \%$ & $2.3 \%$ & $5.5 \%$ & $1.8 \%$ & $3.1 \%$ & $10.2 \%$ \\
\hline \multicolumn{8}{|c|}{ Implied Profits Changes (70-100\%) } \\
\hline- & Small Firms & $0.3 \%$ & $0.0 \%$ & $0.0 \%$ & $0.4 \%$ & $1.3 \%$ & $6.2 \%$ \\
\hline- & Large Firms & $3.2 \%$ & $4.1 \%$ & $9.8 \%$ & $3.2 \%$ & $6.2 \%$ & $19.8 \%$ \\
\hline \multicolumn{2}{|c|}{ Definition of 'large' and 'small' } & $\begin{array}{l}>30 \text { th } \\
\text { percent. }\end{array}$ & $\begin{array}{c}>30 \text { th } \\
\text { percent. }\end{array}$ & $\begin{array}{l}>30 \text { th } \\
\text { percent. }\end{array}$ & $\log$ (sales) & $\log$ (sales) & $\log$ (sales) \\
\hline \multicolumn{2}{|c|}{$\begin{array}{l}\text { Components used in computation } \\
\text { of Predicted Abnormal Returns }\end{array}$} & All & $\begin{array}{c}\text { No } \\
\text { industry } \\
\text { FE }\end{array}$ & $\begin{array}{l}\text { Inter- } \\
\text { actions } \\
\text { only }\end{array}$ & All & $\begin{array}{c}\text { No } \\
\text { industry } \\
\text { FE }\end{array}$ & $\begin{array}{l}\text { Inter- } \\
\text { actions } \\
\text { only }\end{array}$ \\
\hline
\end{tabular}

Notes: Table shows the averages of predicted abnormal returns and implied per-period profit changes for large and small firms. Columns 1-3 use a binary sales proxy and columns 4-6 use log sales. See equations (8) and (10) for the underlying specification and Tables 2 and 3, column 2, for the coefficient estimates used. The implied profit changes in rows $2-5$ are based on the assumptions about the pre-post change in the likelihood of CUSFTA's implementation indicated in the table. See text for details (Section 5.3). 